\title{
Accountability for climate change: a research synthesis through the lenses of the integrated thinking approach
}

\author{
Sandro Brunelli \\ Department of Management and Law, \\ University of Rome "Tor Vergata”, Rome, Italy \\ Camilla Falivena \\ CERGAS - SDA Bocconi School of Management, \\ Government Health and Not for Profit Division, Milano, Italy \\ Chiara Carlino \\ Department of Management and Law, \\ University of Rome "Tor Vergata", Rome, Italy, and \\ Francesco Venuti \\ Department of Financial Reporting and Audit, ESCP Business School, Turin, Italy
}

\begin{abstract}
Purpose - The increasing responsibility of organisations towards society and the environment has inverted the relationship between accounting and accountability, leading to accountability-based accounting systems. This study aims to explore the debate on accountability for climate change within the integrating thinking (IT) perspective. Ascertaining the most significant trends in the debate around purposes and performance that characterise climate mitigation engagement and their connections, the study would explore if and to what extent organisations are tackling climate actions.

Design/methodology/approach - A narrative review of the extensive academic literature developed from the Kyoto Protocol to date was performed. After selecting a representative sample, papers were analysed with the support of a new analytical framework that involves three dimensions answerability, enforcement and outcome - and governance schemes that emerge from the involvement of the private and public sector and civil society. With the support of NVivo software, themes arisen were analysed and coded. Key items were labelled, creating specific nodes and synthesised into the proposed framework.
\end{abstract}

(C) Sandro Brunelli, Camilla Falivena, Chiara Carlino and Francesco Venuti. Published by Emerald Publishing Limited. This article is published under the Creative Commons Attribution (CC BY 4.0) licence. Anyone may reproduce, distribute, translate and create derivative works of this article (for both commercial and non-commercial purposes), subject to full attribution to the original publication and authors. The full terms of this licence may be seen at http://creativecommons.org/licences/by/4.0/ legalcode

JEL classification - JEL Code M14, M41, M48

The authors are grateful the Guest Editors of this Special Issue on Integrated Thinking and the anonymous reviewers for the continuous stimuli received throughout the whole review process, which had definitely improved the impact of their research.

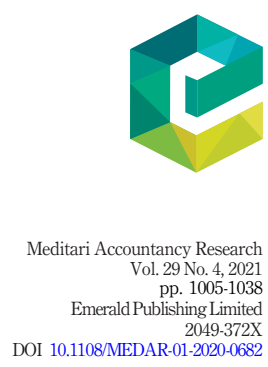

Received 20 January 2020 Revised 19 June 2020 11 October 2020 11 December 2020 Accepted 16 December 2020

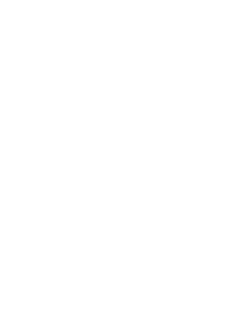


MEDAR 29,4

Findings - A "silo approach" largely characterises the debate on accountability for climate change. The most significant reasons behind the shortcomings of extant climate actions may be retrieved firstly in the weakness of the motivations that guide organisations to operate in a climate-friendly way.

Social implications - This study underlines the need for a $360^{\circ}$ integrated approach for strategically tackling climate actions.

Originality/value - This study would represent a further step towards an integrated approach for studying organisations behaviours in the "climate war", embracing the connectivity between purposes and outcomes, capitals and the relationships amongst the various stakeholders.

Keywords Climate change, Accountability, Integrated thinking, Accountability circle, Climate governance, Governance

Paper type Research paper

\section{Introduction}

Integrated thinking (IT) belongs to the attitude of encompassing all the interdependencies amongst the factors which influence the ability to create value. As described in the integrated reporting (IR) Framework, it is "the active consideration by an organisation of the relationships between its various operating and functional units and the capitals that the organisations use or affect" (IIRC, 2013, p. 2). In accordance with the World Intellectual Capital Initiative (2013), the IT concept involves two dimensions. On the one hand, it refers to the connections amongst the internal departments of an organisation; on the other, it concerns the connectivity amongst strategy, governance, performance and outcomes. Over the years, many contributions aimed at providing an understanding of how IT should be catalysed into organisations, both theoretically and practically, using different lenses and across organisations (Churet et al., 2014; Vesty et al., 2015; Oliver et al., 2016; Dumay and Dai, 2017). However, IT is still largely considered the most significant driver for the needful change of behaviours in facing recent dares.

Amongst various challenges, climate change represents probably the most pressing one (IIRC, 2019), which musters the interest of numerous fields of research. Using the jargon of Coulson et al. (2015), a fair climate is a "store of value" we got from the past. Thus, either preserving its status or fostering its recovery is at the core of the whole society's engagement. IT and its natural extension IR (Al-Htaybat and von AlbertiAlhtaybat, 2017, p. 1436) are powerful tools to move in that direction. IR, indeed, has sharply renewed ways to be accountable by organisations. Although stimulating the interest of several scholars for understanding the state of the art in academia (Dumay et al., 2016; Vitolla et al., 2019) and its magnitude on accountability into a specific context (Silvestri et al., 2017), IR suffered from significant criticism by many scholars (Solomon and Maroun, 2012; Milne and Gray, 2013; Churet et al., 2014; Dillard and Brown, 2014; Lai et al., 2014; Atkins et al., 2015; Barter, 2015; Flower, 2015; Melloni et al., 2016; Mio and Fasan, 2016; Du Toit et al., 2017; McNally et al., 2017; Grassmann et al., 2019). In addition, the overcoming of the traditional accounting centred perspectives (Atkins et al., 2015) leads to a shift from accounting-based accountability to accountability-based accounting (Dillard and Vinnari, 2019), engendering accountability-related issues. This more inclusive concept of critical dialogical accountability (Bebbington et al., 2007) requires practical frameworks, standards and tools to support national and supranational initiatives and to boost engagement of the various actors. Although adopting an IT lens for exploring accountability in the climate change babel is like motherhood and apple pie, there are scant academic studies to date aimed at comprehensively exploring the mostly debated emerging themes of accountability for climate change and the related avenues 
for future research studies. As stated by Rached (2016, p. 319), accountability systems can be summarised as "accounts to B for $\mathrm{K}$ acts, based on X standards, through $\mathrm{Y}$ procedures, at time Z, subject to Q consequences”. Referring to climate action, scholars have focussed their attention on the analysis of accountability in terms of governance or processes, without providing a fully integrated overview. Undoubtedly, the numerosity and complexity that characterise existing initiatives in struggling with climate change firstly require an analysis of promoters, governance and aims. In this regard, Widerberg et al. (2016) represented the emerging global climate change governance through a pyramid composed of seven triangles, which refer to Public, Private and Civil and Society Organisations (CSO) initiatives autonomously, in pairs or triplet. This debate shows that the transnational climate governance has engendered a shift from the United Nations (UN) multilateral level to a networked and more intricate structure, where transparency, monitoring and reporting are not satisfied yet and the availability and usefulness of sanctions are still poorly understood. Furthermore, despite the formal awareness of organisations' accountability towards climate actions' ultimate impacts, the governance complexity, the related enforcement processes and the number of actors involved may be counterproductive in the definition of transparent accountability relationships. The consequences of these weaknesses are vague sanctions and reward systems, as well as a lack of responsibility at all levels.

Many scholars, therefore, are calling attention to new integrated accountability systems that may be able to face the growing complexity of the modern world and the global challenges that ceaselessly arise. Consistently to IT philosophy, a first step is dismissing the idea of reporting as a mere output to communicate performances, considering IT as a critical milestone for improving decision-making, accountability and communication (IIRC, 2016). Such an approach has been reflected on valuable contributions to IT (Barnabè and Giorgino, 2013; Busco et al., 2013; CGMA, 2014; Mio, 2016; Al-Htaybat and von Alberti-Alhtaybat, 2017) which overcame the "silos approach" that has characterised the traditional corporate reporting paradigm.

In view of the above considerations, this paper represents an attempt to review the academic literature on accountability for climate change developed from 1998 to date, providing a new integrated conceptual framework. IT represented the lens for the analysis, fostering the understanding of how organisations strategically tackle climate-related challenges and the identification of the most significant relationship and trends (Task Force on Climate-related Financial disclosure, 2020).

With the aim to adopt a holistic approach still neglected in studies on accountability processes and outputs (Dumay and Dai, 2017; Busco et al., 2018) and moving further from Widerberg et al. (2016), the narrative literature review was performed under three dimensions: answerability (A), enforcement (E) and outcome (O). Each dimension holds the most critical open-ended questions which have shaped the relationships amongst the manifold actors involved in the backdrop of climate change and have characterised the discourse over accountability so far. Of the three dimensions, $\mathrm{A}$ and $\mathrm{E}$ have been retrieved by previous literature in political science (Schedler et al., 1999; Grant and Keohane, 2005) and environmental economics fields (Deveraux Jennings and Zandbergen, 1995; Macho-Stadler and Perez-Castrillo, 2006) and enlarged to better explore the topic. O, instead, is a more discretional dimension we have chosen for checking to what extent initiatives undertaken have achieved their purposes and how academic scholars have read them through their lenses.

The integration of these three dimensions led to the "AEO" Accountability Circle, revolving around the climate governance triangle developed by Widerberg et al. (2016), 
MEDAR 29,4

1008

which represents the analytical framework to support the analysis of the literature. Indeed, the AEO Accountability Circle represents a way to bind existing governance schemes for climate change to the need to unpack accountability instances according to the integrated framework proposed. To provide a picture of the most significant patterns in the academic debate, each dimension has been exploited individuating sub-research nodes through the use of the NVivo 12 Software Package. Highlighting the debated issues in the literature of accountability for climate change, we aimed at stimulating a reflection on the need for an IT approach around the pluralistic relationships amongst the various actors in the babel of climate change initiatives.

This study would represent a former attempt to narrow and explore the debate on accountability for climate change. Besides, it would be a matter of interest for policymakers interested in boosting and leaning existing initiatives by capturing existing overlapping and elaborate schemes. Finally, by analysing the specific theme of climate change within the ground of the IT philosophy, this study would represent an opportunity to better address climate-related issues in the ongoing developments and revision of the IR framework (IIRC, 2020a, 2020b).

The paper proceeds as follows: Section I provides a snapshot about accountability and its nature from the IT perspective, bridging it with the climate change paradigm; Section II points out the method used to analyse the existing literature through the lenses of the proposed accountability for climate change framework; Section III and its subparagraphs, presents the narrative research synthesis of the academic discourse over climate change accountability; Section IV resumes evidence achieved through the IT lenses and Section V provides concluding remarks and avenues for future research.

\section{The evolution of accountability claims in the landscape of the social and environmental accounting literature}

Etymologically, the term accountability refers to the attitude to account. Into the accounting field, it has been adopted for indicating a broad responsibility of an individual or group of individuals (accounts) for the results achieved by an organisation with a particular focus on the public sector. Bellucci and Manetti (2017) claimed that organisations use instruments of external accountability to influence or manipulate stakeholder perceptions. If the content of communications is perceived to be false, misleading or not aligned with expectations, the public as a whole can sanction corporations through media campaigns, divestment and lawsuits. Based on the attitude of organisations in reporting practices, Unerman (2007) proposed a distinction between strategic and holistic accountability concerning. Such a distinction is consistent with the notions of the contractual and communal accountability developed by Laughlin (1996). Strategic accountability reflects a short-term orientation, which implies a classification of stakeholders according to their economic magnitude on the disclosing organisation. Conversely, holistic accountability refers to the attempt of meeting the needs of a broader group of stakeholders.

As stated by Bowen and Wittneben (2011), accounting and accountability are heavily interwoven. The attitude to account should not represent just a way to communicate firm performance, but it is an action to be accountable to the current stakeholders and to future generations (van Liempd and Busch, 2013). Traditional corporate practices have grounded the concept of accountability on that of accounting, limiting the accountability to what is disclosed according to the extant accounting system for years. New social and environmental dares require an overturn of this relation, with accounting systems to support the new accountability systems characterised by numerous and often conflicting, interests (Dillard and Vinnari, 2019). The shift from accounting-based accountability to 
accountability-based accounting stems from several types of relationships amongst stakeholders (Biermann and Gupta, 2011) and affect both internal and external levels (Keohane, 2003).

Therefore, the analysis of accountability-related issues have to address five issues: Who is liable or accountable to whom? What are they liable to be called to account for? By what standards are accountable behaviour to be judged? Through what means is accountability ensured? What are the implications if accountability standards are breached? (Hayley and Dryzek, 2014).

Focussing on climate change, so far, the debate on accountability addressed, in particular, the design stage of governance initiatives and the development of accounting practices for being accountable in practice (Newell, 2008; Bowen and Wittneben, 2011; Hoffmann, 2011). However, providing an advanced and integrated framework to enlarge the areas of disclosure does not reflect an improvement of accountability (Dillard and Vinnari, 2019). Besides integrating financial and non-financial information, there is the need for integrated thinking of an accountability system, which points out the "connectivity" (Busco et al., 2013) of various interest groups.

Besides this general consideration, providing a portray of the sub-strand of accountability for climate change, using the IT mindset, seems desirable in light of different and complementary considerations. Firstly, as noted by Pitrakkos and Maroun (2019, p. 556), using the lenses of Suchman's (1995, p. 574) legitimacy theory approach, desirable actions are required "especially [...] when adverse events or circumstances draw the public attention to a company's environmental and social performance". In this sense, disentangling the climate accountability babel is of utmost importance for answering how organisations (public, private and civil society, following the partition made by Widerberg et al., 2016) are reacting to global policies implemented (above all the Paris Agreement and United Nations SDGs). Secondly, from a policy-oriented perspective, the nexus thinking, seen as "linkages between multiple distinct entities amongst sectors, scales and regions" (Liu et al., 2018, p. 466) can be used for answering several calls for more research between environmental policy and private sector actors (Dahlmann and Bullock, 2020). Thirdly, it would be a matter of interest seeking how scholars are weighing public pressures on climate actions underway; fourthly, a theoretical framework of studies on accountability for climate changes may represent a foundation for narrowing the debate in the future. Thus, following Adams (2017), rather than focussing specifically on one theory, this paper takes a holistic approach to draw out an extensive reading of this underexplored and wide field of research. Inspired by IT principles, the challenge is to develop an analytical framework for exploring the theme of accountability for climate change looking at the governance, the strategy, the operations and the outcome.

\section{Method}

\section{The climate change accountability circle analytical framework}

In climate change, as well as in numerous areas of sustainability, a transnational complex regime characterised by the collaboration amongst public, private and/or non-profit organisations has replaced top-down initiatives. This led to a fragmented and decentralised climate change governance, where activities and responsibilities are shared amongst organisations, which operate at different levels and across countries pursuing individual and collective interests (Abbott, 2012). Therefore, public-private partnerships made outmoded traditional approaches for studying accountability. Consequently, there has been the need for frameworks aimed at representing a lens for examining accountability (Hoffmann, 2016), whose first task is understanding climate change governance architecture 
MEDAR 29,4

1010

(Biermann et al., 2009; Kramarz and Park, 2016). To do that, Widerberg et al. (2016) developed a global climate change governance triangle (Figure 1) identifying seven forms of collaboration amongst the various types of actors involved. While the vertexes (1-3) groups the initiatives fostered by a single type of actor (public, private or CSO), the central zone (7) indicates the involvement of all three types of actors. The remaining zones refer to hybrid initiatives: 4 for those promoted by public and private organisations; 5 for actions by public and CSO; 6 for the hybrid engendered by the collaboration between the private sector and CSO.

Following prior literature on accountability (Mashaw, 2006; Unerman, 2007; Hayley and Dryzek, 2014; Silvestri et al., 2017), this study attempted to provide an overview of the most significant patterns emerging in the debate around the governance of climate change and how the multiple actors have engaged their commitment. To do that, we developed an analytical framework grounded on the climate change triangle for comprehensively analysing academic literature. To answer the above-mentioned questions, we identified three main dimensions:

(1) Answerability (A) for exploring most significant academic positions around the motivations that have moved climate actions.

(2) Enforcement (E) for mapping the mechanisms which have been implemented.

(3) Outcome $(\mathrm{O})$ for probing the ultimate implications of climate change commitment, reflecting current performance and future prospects.

Figure 2 illustrates the "Climate Change Accountability Circle” Analytical Framework.

\section{Literature review process}

First of all, we performed a search for articles on Business Source Complete and EconLit databases by keywords "accountability"; "accounting"; "reporting"; "transparency", in a combined manner, together with the primary keyword "climate change" into the abstract.

Figure 1.

Climate change governance triangle

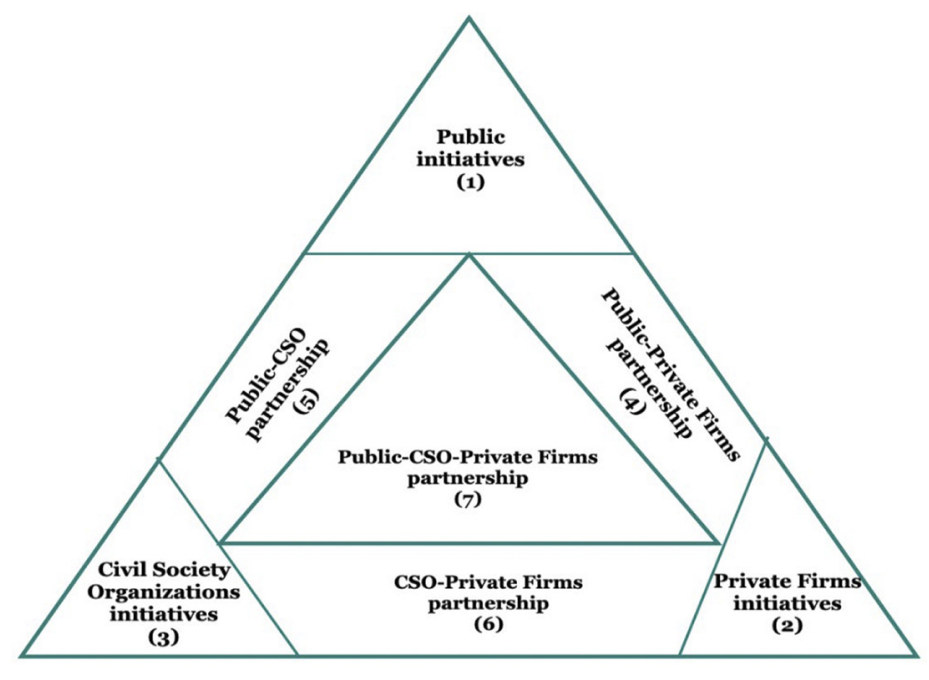

Source: Authors' adaptation from Widerberg et al. (2016) 


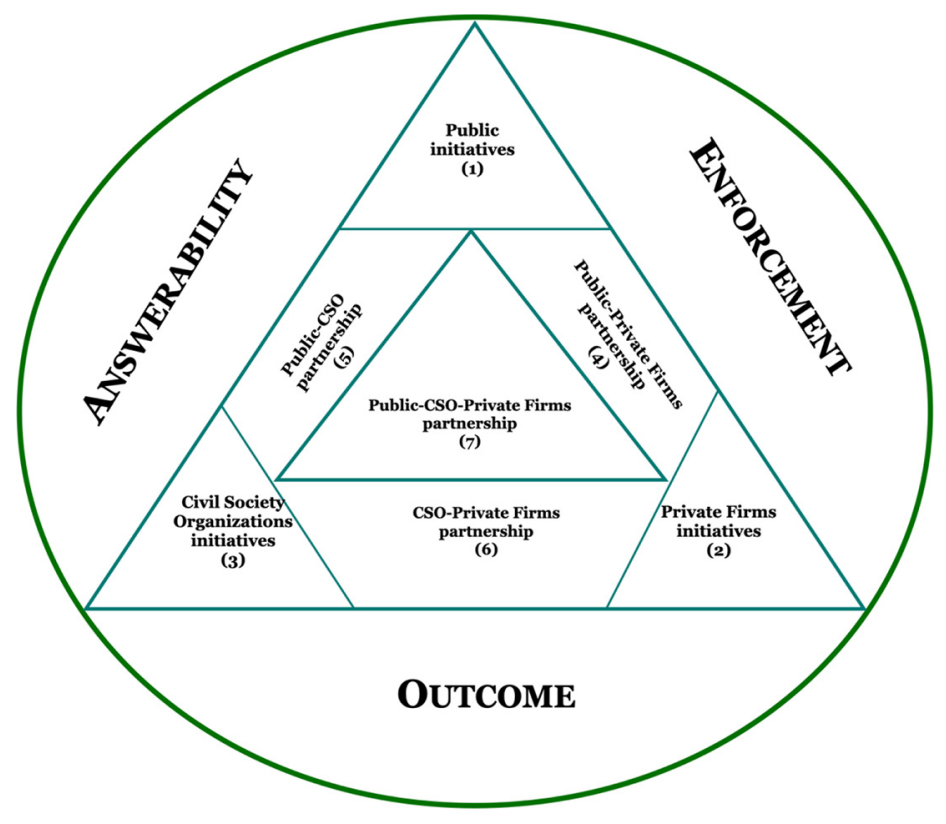

Source: Authors' elaboration
Climate change

1011
Figure 2.

The climate change accountability circle analytical framework

The purpose of this phase was to collect all the studies that address the issue of accountability for climate change. The selection of the studies grounded on the responsiveness to the following questions:

Q1. Why do public institutions, private companies and civil society organisations engage in climate change?

Q2. How is climate mitigation action carried out?

Q3. What are the ultimate effects of climate change commitment?

The terms "governance"; "stakeholder"; "auditor" were, in turn, combined with the main keywords to tackle the issue, to seek studies that address the question, the search was performed by adding the keywords "policy"; "regulation"; "standard"; "process"; "law"; "manag*". Finally, the words "performance", "effect" and "impact" was used for narrowing the analysis on the implications of climate mitigation efforts, in sum, 48 combinations of keywords were used, which lead to an overall result of 2,642 articles. To increase the reliability of the literature review, criteria of language, time and quality were established. Therefore, only studies are written in English and published after 1998 (when the Kyoto Protocol was signed) were included. The adherence to quality standards was assured by involving only peer-reviewed articles and excluding book chapters, reports, conference proceedings, commentaries and editorials. In this way, the sample was shortened to 1,331 studies, as 659 were duplicated. In total, 272 abstracts were selected and underwent a subsequent reading of the entire paper. All papers were entirely read, the quality assessed by two reviewers and, then, two reviewers were appointed at overhauling the entire 
MEDAR 29,4

1012

selection process for testing the validity of literature review. The selection of papers was based on their relevance to at least one of the "why", "how" and "what" questions mentioned earlier.

In the end, 86 papers composed the final sample on which qualitative content analysis was performed with the support of the NVivo 12 software package. Included studies were classified according to year; journal; scientific field(s) based on SCImago Journal Rankings; governance architecture based on Widerberg et al. (2016) classification; accountability dimension(s) addressed [Classification Sheet in Appendix 1].

The screening of the papers was conducted through the lens of "The Accounting Circle" analytical framework (Massaro et al., 2016). Adopting deductive coding, the three dimensions (A, E, O) represented the predetermined cases for classifying the studies involved in the sample. Once that each selected paper has been assigned to one or more areas of inquiry, a query for exploring word frequency was performed within each dimension. In this way, we obtained a "word cloud" containing the most used words for each dimension that were selected, focussing on their relevance in representing the most significant trends in accountability for climate change debate. These words represented the keywords for performing a second query on NVivo 12 aimed to search all sources containing them. The output was a "word tree" which allowed us to identify the context in which they were used. The various themes addressed represented the codes used to label and assign units of meaning to the descriptive information (Miles and Huberman, 1994). This approach is consistent with the content analysis "meaning-oriented", aimed at inferring the underlying meanings included in the texts (Smith, 2003). In social science, where meanings and interpretations are critical for exploring phenomena, the content analysis is "potentially one of the most important research techniques" (Krippendorff, 2004, p. 18). However, the role of research in interpreting the text without any influence by the scope of its analysis represents a critical issue to manage when adopting this research methodology (Steenkamp and Northcott, 2008). Figure 3 illustrates the steps which were followed to critically analyse the literature.

\section{Results}

\section{Actors involved and their motivations}

Climate change has been widely perceived as a highly important issue. Besides tackling risks and uncertainties associated with climate change (i.e. reputation risk, increased insurance costs, cost of compliance with future regulations, reduction in consumer confidence), companies have to face pressures from many groups of stakeholders. While consumers demand climate-friendly products (Eleftheriadis and Anagnostopoulou, 2014), government bodies, institutional investors, media and non-governmental organisations (NGO) ask for an increasing disclosure of information concerning climate mitigation commitment on annual reports, company websites and, to a lesser extent, on a stand-alone social/environmental report (Haque and Azizul Islam, 2015). Because of media have a critical role in promoting an understanding of risk related to climate change, pressures from stakeholders raise if media attention increase. As Haque and Azizul Islam (2015) observed for Australian companies, there is a close association between stakeholder concerns and media attention. Such a relationship fosters companies' participation in initiatives such as the Carbon Disclosure Project (CDP).

Moreover, it stimulated the dissemination of regulatory requirements, which represent another way of coercive pressure (Haque and Azizul Islam, 2015). Comparing sectors subjected to different regulatory regimes, Brouhle and Harrington (2009) recorded a higher level of participation in climate action in heavily regulated industries (e.g. petroleum, electric 


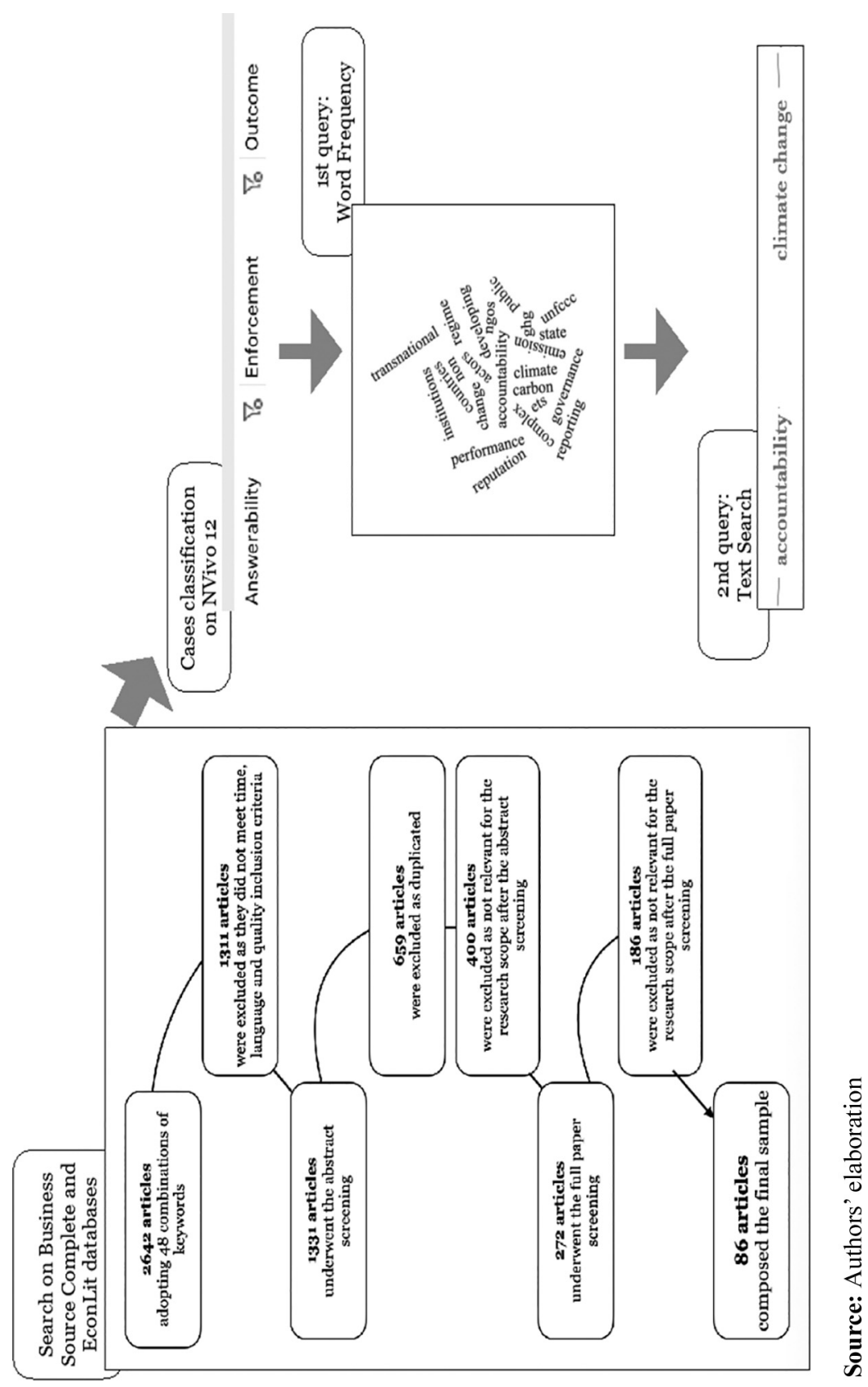

Climate change

1013

Figure 3. Literature review process 
MEDAR 29,4

1014

utilities). A lack of regulation and best practice guidelines from the regulatory bodies is considered the primary reason for the non-disclosure attitude to reporting for climate change in Bangladesh (Nurunnabi, 2016). Most firms focus more on regulatory response measures, as they perceived more regulatory risks than physical and market risks. Physical risks are expected to materialise in the more distant future, while the realisation of market risks is considered rather unlikely (Sakhel, 2017). Within this debate, the National Greenhouse and Energy Reporting (NGER) scheme developed in Australia is a compelling case. The key actors involved in NGER are companies and green groups. Australia is one of the highest emitting countries (Haque and Irvine, 2018), presenting the highest per capita level of emissions in the world (Haque and Azizul Islam, 2015). In the view of this consciousness, on the one hand; and supported by the confidence with reporting for accountability, on the other, the NGER policy agenda has been widely accepted by the business community (Lodhia and Martin, 2012).

External pressure represents determinant leverage not only to meet mandatory regulations but also to enhance voluntary disclosure (Liesen et al., 2015) and transparency (Giannarakis et al., 2017). However, significant issues such as the logging of native forests and its impact on climate change have not become an integral part of corporate strategy yet (Brander, 2017). In the insurance sector, for example, the majority of companies do not integrate climate change into their risk management practices (Eleftheriadis and Anagnostopoulou, 2014). Firms with nested logic, in particular, believed the adaptation to short-term climate variability is an effective response to climate change (Thistlethwaite and Wood, 2018). Managers tend to see climate action as a response to a problem rather than an inclusive strategy (Kumarasiri and Gunasekarage, 2017). For example, firms more exposed to excessive risks are more likely to be assured of carbon emissions (Datt et al., 2018). This may depend on the fact that environmental and climate-related issues heavily called upon green groups are still separated from economic interests, which remain the primary concern of company stakeholders (Lodhia and Martin, 2012). Adopting CSR reporting in the oil industry as a proxy of commitment to climate change, Jaworska (2018) observed a propensity of shifting the responsibility for climate change to other stakeholders or to the future in the belief that the market and technology are the only solutions to ecological problems. Organisations require that suppliers and other stakeholder groups take their responsibility to effectively tackle climate change (Ferguson et al., 2016).

Sometimes the leverage for a higher commitment could be represented by the advantage of a more sustainability-oriented competitor, as demonstrated by Kraft (2018) referring to polluting industries. These industries often do not operate in competitive markets. Therefore, results concerning the level of disclosure may be invalidated by competition rules. Although the influence of regulatory pressure, stakeholders do not have much power in a monopolistic market. The author found that increasing the competition, their power increased, leading to a higher level of disclosure. Competition and collaboration amongst firms are even crucial in promoting an understanding of climate change and its aftermaths. Analysing cluster and extra-cluster effects within the wine industry, Galbreath et al. (2014) found that firms acquire knowledge around climate issues both from a variety of exchanges with other firms and from other knowledge sources.

Besides the above-explained issues, several studies dealt with the identification of critical factors that shape the willingness to voluntarily disclose for climate change. Overall, firm size is one of the most significant features that positively affects the level of disclosure (Stanny and Ely, 2008; Eleftheriadis and Anagnostopoulou, 2014; Nurunnabi, 2016). However, while larger companies tend to be more accountable to government and society as 
a whole, firms facing public, political and social pressure disseminate less information (Giannarakis et al., 2017).

Even from a geographical point of view, different trends may be observed. First of all, the availability of resources influences the propensity at reporting between developing and developed countries (Luo et al., 2013). Moreover, Gallego-Álvarez (2012) discovered that the location of headquarters is directly related to the attitude to disclose and to attain good environmental performance. In particular, the author found that companies, which have their headquarters in countries that have ratified the Kyoto Protocol are more active towards climate change mitigation (Amran et al., 2014; Ascui and Lovell, 2012). A different approach to tackling the climate question has been recognised between Europe and America. While European organisations are more engaged in reporting activities and the debate around governance issues, the American ones are more active in investing in technologies, which may support climate action (Backman et al., 2017). Surprisingly, Nurunnabi (2016) observed little engagement by multinational companies, even though they are not influenced by their country of origin (Grauel and Gotthardt, 2016).

The ownership of the company (Nurunnabi, 2016) and the characteristics of the board (Ben-Amar and McIlkenny, 2015; Liao et al., 2015; Jaggi et al., 2018) matter on the level of transparency. In particular, culture exerts incremental influences beyond economic and regulatory incentives (Liao et al., 2015). Balanced gender diversity and independence of directors within the board increase the tendency to be environmental-oriented. Such an approach, together with attention to certification, may bear climate action also in developing countries (Amran et al., 2014).

The availability of tools aimed to sustain investment decisions, providing information on the firm's position within environmental perspective alongside financial information represents a novelty both for people who are going to invest and for the broader users' group (Andrew and Cortese, 2011). To make these instruments effective, there is a need for strong support from institutional investors (Cotter and Najah, 2012). Effects of domestic institutional efforts, in particular, are positively associated with disclosure attitude (Wegener et al., 2013). Within this context, also internal and external auditors have a critical role, that varies from precise control of compliance to the issue of penalties for misreporting (Trotman and Trotman, 2015).

However, efforts towards climate change mitigation do not involve only the private sector. Several studies addressed the role of public and non-profit sectors in sustaining the cause and promoting accountability and participation of all members of society (Bäckstrand, 2008; Newell, 2008; Kuyper and Bäckstrand, 2016; Kuyper et al., 2017; Widerberg and Pattberg, 2017). The involvement of most of the representative stakeholders may allow overcoming the lack of normative statements. Scobie (2018) provided the example of Caribbean Regions where the cooperation amongst regional organisations, national government departments, agencies, environmental NGOs and the private sector lead to the development of effective internal and external accountability mechanisms. From a social perspective, NGOs are fundamental to increase the inclusiveness of climate initiatives. They are, in particular, appointed at boosting the participation of emerging economies and stakeholders from all levels (Dombrowski, 2010). In some cases, their endeavours have paved the way for the development of standards for calculating and reporting emissions (Green, 2010). Although so far accountancy professions have been the most involved in climate change accountability debate (Ascui and Lovell, 2012), there is an emerging landscape represented by the converge arisen from public norms and private rules (Green, 2013). 
MEDAR

29,4

1016

\section{Climate change responses by organisations and networks}

Over the years, efforts to struggle with climate changes have been aimed at stimulating behaviour changes towards more environmental-oriented practices both amongst the population and amongst companies and at developing measures to translate ecological concerns into accounting information (Bebbington and Larrinaga-Gonzaléz, 2008). Indeed, as the impacts of climate change on organisations are increasing, there is a growing need for decision-relevant information concerning risks, economic implications and adaptive capacity (Linnenluecke et al., 2015). To that end, several types of emission account methods and reporting schemes have been developed for monitoring how companies tackle climate change questions. Traditional corporate inventories and other forms of attributional accounting are not suitable for evaluating mitigation actions. Their usefulness may regard the attribution of responsibility amongst the various emissions sources. Therefore, the most significant references at organisational level are carbon accounting and greenhouse gas (GHG) emissions accounting.

Within carbon accounting, Schaltegger and Csutora (2012) identified two main approaches: accounting for un-sustainability and accounting for sustainability improvements. The former aims to the disclosure of un-sustainability referring to past and current operations and at forecasting future levels of emissions. The latter informs about the decisions - and related measures - that a company is going to implement for improving its environmental performance. At all levels, both two approaches are needed for understanding the entity of the actual magnitude and for developing effective policies. Reviewing the development of carbon accounting, Csutora and Harangozo (2017) identified a large room for improvements. From a methodological perspective, current practices are characterised by top-down and hybrid approaches. Moreover, carbon management remains a separate dimension regarding the overall management. This way, system boundaries are still weakly settled and double counting is frequent. Some methods, such as the emerging market-based approach, may provide misleading information, undermining efforts for mitigating impacts and moving towards renewable energies (Brander et al., 2018). Carbon footprint, instead, may have significant implications on the allocation of responsibilities both between importing nations and exporting nations and between consumers and producers (Harris et al., 2012; Turner, 2014).

Amongst the consequential techniques to evaluate climate-related policies, the project method appears to be better than the Life-Cycle Assessment (LCA) due to its higher easy-touse and the ability to monitor the impacts over time (Brander, 2017). Moreover, the extant methodologies for the environmental assessment of projects often refer only to the initial phase. To fill this gap, Abdi et al. (2018) proposed a model based on the logic used in earned value management, which allows estimating the environmental impact throughout the whole life of a project. However, the new proposed solutions for supporting the evaluation of projects aimed to reduce their magnitude on the environment cannot involve all the issues related to the technology advancement (Hendrickson et al., 2016).

For what concerns NGOs and municipalities, responses to climate action were aimed at increasing the involvement of emerging countries and societal stakeholders from all levels through the development of standards of participation and representation (Zengerling, 2018). Other types of initiatives attempt to guarantee broader inclusiveness within decisionmaking processes by structured climate action networks (Dombrowski, 2010).

Therefore, current experiences performed at all levels and within the different sectors underlined that climate change commitment is still inadequate. Reports contain several repetitions and the integration between financial and non-financial dimensions is weak (Atkins et al., 2015). Part of the problem stems from the ambition to integrate environmental 
issues into international financial standards without compromise their conceptual nature (Lovell, 2014). Furthermore, voluntary reporting schemes (i.e. NGER) were revealed to be focussed on the reporting of GHG emissions and energy consumption. This way, informative insights from stakeholders and the identification of potential problems for businesses are neglected (Lodhia and Martin, 2012).

Although good practices of voluntary disclosure have been implemented, the discretionary in adopting them do not allow the involvement of all organisations. Notwithstanding, the introduction of mandatory requirements such as the Carbon Tax in Australia, may lead organisations to reduce their disclosure due to a higher awareness of negative implications (Liu et al., 2017). One of the consequences of this plight is that most developed accounting frameworks have been generated in a national or regional context, reducing their usefulness on an international scale (Andrew and Cortese, 2011).

Overall, attempts of researchers and practitioners are aimed to encourage the attitude to disclose. Nonetheless, the growth in the quantity was not supported by an improvement in the quality of information disclosed. Analysing data on GHG emissions in the oil and gas industry, Comyns (2016) observed that the average quality of the report was shallow, regardless of firm size. Due to institutional pressures, big companies increase the number of information. Likewise, the commitment of Indonesian companies in GHG emissions disclosure is aimed at legitimating their existence than pursuing an environmental strategy (Faisal et al., 2018). Even responses to CDP demonstrate the apparent success of this initiative. Although the participation is high, comprehensibility of disclosures and actual achievement of desired performance is still questionable (Kolk et al., 2008). In several cases, managers tend to prefer corporate reporting to CDP due to the opportunity of "customising" the disclosure according to the different stakeholder groups (Depoers et al., 2016). For what concerns NGO, efforts in reporting environmental performance are often higher than the environmental performance itself (Haque and Irvine, 2018).

Linguistic strategies jeopardise the reliability of communications related to climate change. The analysis carried out by Ferguson et al. (2016) revealed that, over time, companies are moving from asserting that they are pursuing the interest of stakeholders rather than the own ones to shift responsibilities to other stakeholders such as government and suppliers. In Australia, in particular, less carbon-intensive sectors are inclined to adopt a symbolic disclosure strategy according to the intensity of the social debate around climate change, global warming and carbon footprints (Hrasky, 2011). Sometimes, the actual number of emissions may be dodged by the confusion between domestic and imported/ exported emissions (Mózner, 2013). Talbot and Boiral (2018) identified four impression management strategies for GHG reporting. The two concealment strategies concern the strategic omission or the manipulation of data. The two neutralisation techniques consist of minimising the importance of non-disclosed emissions or in excuses and promise of future commitment.

As carbon-emission management reckons with several strategic dimensions (Ratnatunga and Balachandran, 2009), limits of existing practices lay on a weak integration of climate action into the overall strategy. Over time strategies pursued by companies have changed: for a while, there was a proactive and creating approach; currently, reactive strategies are prevalent (Bui and de Villiers, 2017). Reasons behind such a situation may be recognised into normative pressures, which bear a misalignment between climate policy and its translation at the organisational level (Cadez and Guilding, 2017). For example, while adopting long-term emission management measures, the majority of companies with more substantial relative emissions do not follow a specific strategy of emission reduction (Weinhofer and Hoffmann, 2010). Otherwise, firms strive for symbolically demonstrating 
MEDAR 29,4 their attendance to reporting guidelines, without pursuing a strategy for improvement substantively (Haque and Ntim, 2018). In China, for example, companies do not openly mention climate change in their report, as the Chinese government promoted a policy of industry restructuration and energy-savings (Yang and Farley, 2016).

The prevalence of climate management for external disclosure at the expense of an internal strategy is confirmed by the lack of studies fitting into the management control area. Management accounting techniques are seen as tools for defending economic interests and reducing external pressures (Kumarasiri and Gunasekarage, 2017). Leaving aside some limitations related to the nature of management control studies and the difficulty of measuring non-financial dimensions (Hartmann et al., 2013), the absence of such a perspective undermines risk management assessment (Bui and de Villiers, 2017) and a joined carbon management strategy (Burritt et al., 2011). A cost and management accounting perspective, indeed, may provide useful insights around carbon cost structures. The relevance of this information is demonstrated by the study performed by Cadez and Guilding (2017). When the product drives the level of emissions, carbon costs are mainly variable. If the consumption of carbon-related resources is driven by capacity, a company has a harsh cost structure. When the number of emissions depends on both product and capacity, the cost structure is semi-variable.

At least seven reasons may unfurl the scant of interest for the development of effective climate action (Birnik, 2013). However, as Knox-Hayes and Levy (2011) underlined the importance of the participation of all of the stakeholder groups for promoting effective carbon mitigation goals (Haque and Azizul Islam, 2015; Blanco et al., 2017). Alliances between nations can foster intergovernmental forums, as well as forms of private authority, also involving firms and NGOs, which have served both de facto and de jure global as rulemakers (Green, 2013). These forms of collaboration are critical within a transnational regime complex (Bäckstrand, 2008; Widerberg and Pattberg, 2017).

\section{Ultimate effects of climate change commitment}

The majority of scholars have addressed determinants and approaches to climate commitment reporting. Recently, it has been developing a research strand aimed at exploring outcomes engendered by efforts of the various actors involved. While the output is strictly related to the immediate results of an action (such as disclosure for what concerns climate change engagement), outcome refers to ultimate implications on performance and behaviours for facing the subsequent challenges (Hahn et al., 2015). The intensity of energy employment and regulations tend to influence corporate response to climate change question, but not its aftermaths. Neither the presence of mandatory reporting requirements has been revealed to be a relevant determinant for superior efficiency (Gabe, 2016). Besides the reporting attitude, implications deriving from programme implementation are strongly related even to the ways by which information is disclosed (Matisoff, 2013).

So far, management techniques for reducing emissions have provided little or void benefits (Evangelinos et al., 2015). Doda et al. (2016) attempted to justify this result with the absence of a standardised reporting approach and an insufficient impact orientation. Ioannou et al. (2016), instead, asserted that a higher target difficulty positively affects the likelihood of target completion from a long-term and non-financial perspective.

Several studies dealt with the overall impact of climate strategy on the performance from financial and non-financial perspectives. Despite the differences in reporting attitude amongst the sectors, Tang and Demeritt (2018) did not find specific patterns in the impact on the performance and on stakeholder relationship. Generally, efforts in sustainability practices do not favour a "halo effect", protecting firm value from negative implications due 
to their carbon and gas consumption. Findings disseminated by Cooper et al. (2018) underlined a "fallen angel effect", which contributes to reducing firm value. Adverse effects worsen when companies do not disclose their performance, owing to penalties (Matsumura et al., 2014).

Tackling the question of climate change as a threat and adopting a reactive approach are negatively correlated to environmental performance. This strategy contributes to boosting the rigidity of a company, undermining its smartness to react when a risk occurs (Sakhel, 2017). Conversely, a proactive approach leads to more sustainable performance and higher profitability in a five-year horizon. The integration of climate-related issues within the overall strategy allows companies to reduce risks, on the one hand; and to get the opportunities, on the other (Elijido-Ten, 2017). The depth in the integration influences the ability to attain a competitive advantage over other companies (Giannarakis et al., 2017).

Nonetheless, Lee et al. (2015) observed a negative - and immediate - effect on the capital market return of proactive climate responses. Investors recognise efforts for mitigating environmental magnitude as an adverse event, which is going to endanger additional costs. To mitigate this adverse effect, firms could increase the frequency of voluntary disclosure. The frequency of communication on media channels, indeed, represents a moderating variable. Still, to evaluate the magnitude of responses to climate change on stock performance, Ziegler et al. (2011) analysed portfolios characterised by different environmental performance and considering different sub-sectors and different sub-periods for Europe and the USA separately. The achieved results were that stock performances of companies, which disclose responses to climate change were higher than those of companies, which do not disclose. In terms of time, such a result was particularly evident between 2004 and 2006 in Europe. In terms of sectors, attitude to disclose to climate change rewarded more energy firms in the US. Moreover, the authors found a positive magnitude of institutional climate policy on this relationship. Companies that operate in regions or sectors with more ambitious climate policy regimes reported a slightly higher stock performance.

In the view of CDP responses, Gasbarro et al. (2017) observed a different approach between companies and civil society. While companies recognised both risk and opportunities, civil society focusses more on risks. Attempting to boost the confidence of citizens, NGOs are using massive resources to foster inclusiveness and representativeness (Dombrowski, 2010).

The most significant benefits of a climate strategy perceived by organisations are gaining legitimacy (Haque and Azizul Islam, 2015; Nurunnabi, 2016; Faisal et al., 2018; Li et al., 2018); higher awareness and extensive climate change governance (Turner, 2014; Haque and Azizul Islam, 2015; Scobie, 2016; Widerberg and Pattberg, 2017); increasing accountability (Bebbington and Larrinaga-Gonzaléz, 2008; Kolk et al., 2008; Michalisin and Stinchfield, 2010; Schaltegger and Csutora, 2012; Atkins et al., 2015; Haque and Irvine, 2018).

\section{Discussion: many silos, few integrated views}

IT promotes integration between decision-making and action for creating value over the short, medium and long term. To do that, it takes the connectivity and interdependencies amongst the related elements within value creation (IIRC, 2013). Critical dialogic accountability, for its part, attentions to plenty of ideological orientations and the asymmetrical - but essential - relationships between accounting and accountability (Dillard and Vinnari, 2019). Understanding dialogic accountability processes firstly require the recognition of relevant stakeholders and the plethora of their needs and interests. Starting from the climate change governance triangle and overcoming the "silo thinking" and incorporating all the connections amongst the various factors that shape the behaviours 
MEDAR 29,4 of organisations by the IT lens, the extensive journey into the literature on accountability for climate change revealed more shadows than lights. Moreover, IT philosophy suggests, the analysis of the debate involved the strategy, the performance and the prospects, having the governance schemes as ground.

Over time, scholars have been focussed either on the motivations that steered strategies to manage climate change or how organisations perform their climate action or on the implications and expectations related to their engagement. Anyone has integrated all these aspects, providing a 360-degree perspective. This study, hence, represents an attempt to make the state-of-art of the extant debate, underlying emerging trends from each dimension. The scientific interest in the topic has grown since 2015. Contributions came from all around the world, disregarding sectors, ownership and size of organisations.

In the dimension of Answerability, which deals with the reasons behind the development of a climate strategy, have emerged seven main determinants:

(1) Public pressure;

(2) Regulation;

(3) Perceived risk;

(4) Size;

(5) The concentration of markets;

(6) Location; and

(7) Role of institutional investors.

External pressures represent the first and historical reason, which foster behaviours towards climate change mitigation (Haque and Azizul Islam, 2015) and transparency (Giannarakis et al., 2017). Consistently with the legitimacy theory (Suchman, 1995), more pressures lead to an increased level of disclosure (Liesen et al., 2015). This aspect has been reframed also by Lai et al. (2014) and Melloni et al. (2016) disclosing the attitude of organisations to use integrated reports as tools for legitimizing their strategies; also by using a certain degree of impression management techniques. Amongst the various external pressures, regulation is one of the most significant (Brouhle and Harrington, 2009). Plenty of initiatives, in particular in the private sector, have been encouraged by the introduction of new regulations and the development of mandatory and voluntary reporting frameworks. The power of regulation is recognisable in the risk to incur in sanctions (Sakhel, 2017). The perception of risks that may undermine organisational performance, indeed, represents another factor that impacts the attitude to develop a climate strategy. As happens for other issues, such trends are heavily influenced by the size of the company. Due to the burden of their visibility, large companies tend to disclose more for non-financial aspects than small ones (Stanny and Ely, 2008; Eleftheriadis and Anagnostopoulou, 2014; Nurunnabi, 2016). A lower attitude to disclose over climate change has also been detected in firms, which operate in low-concentrated markets. This may be due to the fact that they expect to be negatively impacted by adverse climate events later in the future (Kraft, 2018). The higher motivations recorded in countries that have signed the Kyoto Protocol may express that even the location matters within the attitude to develop a strategic answer to climate change (Gallego-Álvarez, 2012). As a consequence, the macroeconomic attention to this issue increases the awareness of institutional investors towards the climate strategies developed by companies, which in turn increase their attitude to promote more sustainable practices (Cotter and Najah, 2012). 
The trends arising in the Answerability dimension trigger two kinds of reflection. Firstly, managers tend to see climate actions as a response to specific problems or pressures than as a pillar for a strategy oriented to the future. In detecting so, it is worthwhile to note that both the foundations and principles of the IT approach were completely disregarded (Mio and Fasan, 2016; Dumay and Dai, 2017; Busco et al., 2018). Sadly, a "disintegrated approach" is observable following the scheme: silos for climate - silos for natural capital silos in not connecting capitals - silos in the ultimate disclosure provided (does not matter if formally prepared in accordance or not with the IR framework). Secondly, as the public pressure has a great deal of importance, some actors, especially those operating in highpolluting sectors and industries, used to shift the responsibility on climate changes to other stakeholders, governments and to the future, as the market and future technology developments are seen the only viable solution to the problem (Jaworska, 2018).

The Enforcement dimension that explores how organisations perform their climate action reveals a prevalence of studies fitting into the accounting field. Due to the weak motivations at the ground of organisational climate-related strategies, efforts have been devoted in particular to the translation of good purposes in accounting frameworks (Bebbington and Larrinaga-Gonzaléz, 2008). Most significant outputs are represented by top-down and hybrid approaches guided by popular carbon accounting tools as GHG emissions schemes, Life-Cycle Assessment (LCA), CDP which belong more to accounting for un-sustainability than accounting for sustainability (Schaltegger and Csutora, 2012). Besides reporting practices, unsuccessful results have been achieved in terms of civic participation and representation by NGOs (Zengerling, 2018; Haque and Irvine, 2018). Therefore, many silos are still recognisable even from the Enforcement perspective that point out the weakness of climate-oriented practices and ways to detect the related accountability within integrated reports (Silvestri et al., 2017). Firstly, tools to support climate actions are inadequate, owing in particular to the weak integration between financial and non-financial information (Churet et al., 2014; Atkins et al., 2015). Voluntary reporting schemes have caused mainly such a situation. The high degree of discretion in their implementation and the extensive use of impression management techniques have undermined the comparability and the reliability of information (Comyns, 2016; Ferguson et al., 2016; Melloni et al., 2016). The performance of climate actions, hence, seems to be guided by the conflict amongst the various groups of stakeholders rather than by the substantial awareness to pursue environmental goals.

These trends are also reflected in the Outcome dimension, whose aim is to collect the present and future implications related to climate change engagement by companies and society as a whole. Evidence emerging from the literature suggests we are still far from winning the climate war. Many scholars asserted that the causes might be retrieved in the weakness of management and reporting techniques (Matisoff, 2013; Evangelinos et al., 2015; Doda et al., 2016). In an IT lens, however, to look for the reasons for unsatisfactory results we should go more in-depth, inquiring into the motivations that represent the ground of the climate actions. On the other hand, external pressures, regulation and risks have a positive magnitude to stimulate the commitment of organisations towards climate change mitigation. However, it has not been enough for identifying mandatory and/or voluntary tools to effectively support initiatives (Gabe, 2016) and, consequently, to achieve desired outcomes.

Most of the time, such a situation has occurred because firms have perceived climate change only as a threat, without an inner understanding of the related opportunities both for the companies and for society. This way, all efforts may be wasted. Neither reactive approaches (Sakhel, 2017), nor proactive ones (Lee et al., 2015), indeed, have revealed a 
MEDAR 29,4

1022

positive relationship between social and environmental commitment and firm performance to date. Nay, sustainable purposes in some cases have resulted in a "fallen angel effect" (Cooper et al., 2018), worsening firm value. On the contrary, positive aftermaths were registered when financial markets have recognised a premium for those companies which importantly enhanced their environmental disclosure or when located in Regions with a higher climate policy commitment, demonstrating the importance of the interplays between private and public sectors and between climate governance and related accountability process, output and outcome (Scobie, 2016, 2018).

Emerging patterns of the literature on accountability for climate change from answerability (A), enforcement (E) and outcome (O) are shown within the Climate Change Accountability Circle (Figure 4). The core of the framework is the "The Climate Governance Triangle" developed by Widerberg et al. (2016), while the circles into each dimension represent the key themes arisen [the nodes list is provided in Appendix 2].

Such a lecture, consistently with the IT principles, allows exploring the connection amongst the governance, represented by the "Climate Governance Triangle" at the core of the framework; the strategy, through the Answerability dimension; the performance, within Enforcement perspective; the prospects by the Outcome section. The connectivity amongst these dimensions, on the one hand, revealed the absence of accountable climate action; on the other hand, fosters an understanding of the leverage which needs to be activated to create a climate-friendly value.

Figure 4.

The climate change accountability circle and related nodes

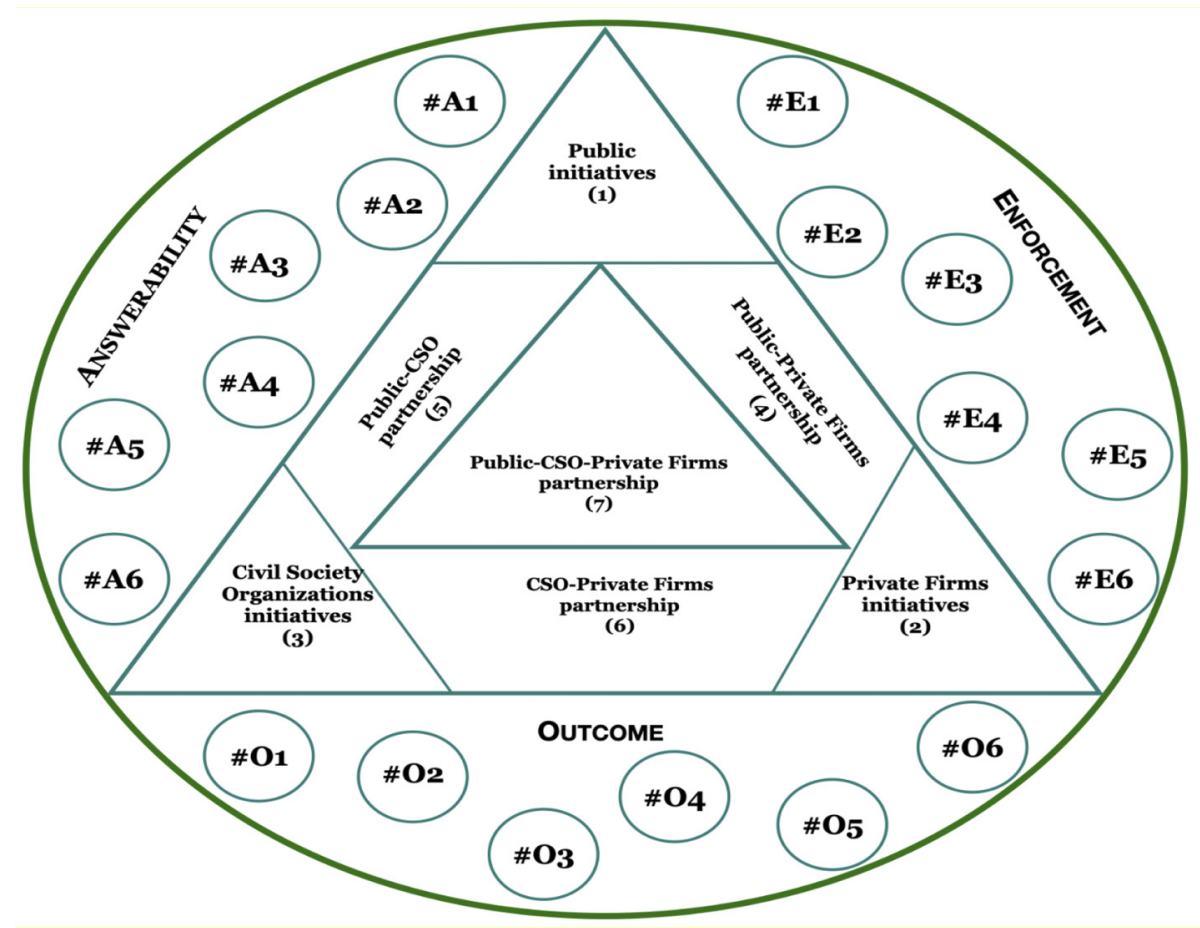

Source: Authors' elaboration 
In more recent years there have been other attempts to provide a new accountability framework grounded on the mutual relationship between existing accountability mechanisms and governance architecture of climate changes, both at the local and supranational level (Lockwood, 2010; Scobie, 2016, 2018). However, an effective transnational regime on climate change seems desirable with the extent to which it is rearranged under clear and linear accountability strategies and a broad agreement around priorities to pursue.

The proposing integrated framework would represent an answer to the call for new conceptual tools arisen from eminent scholars (Bebbington et al., 2007; Atkins et al., 2015; Bellucci and Manetti, 2017; Dillard and Vinnari, 2019) to face the challenges of the accountability-based accounting era. Furthermore, the urgency of climate change has pointed out the necessity to overcome the different and sometimes divergent individual interests towards a common goal. While new models are underway to estimate the environmental impact on projects and activities (Abdi et al., 2018), mistakes from the past must be avoided break-downing the silos approach that has characterised the enforcement actions undertaken up to date.

\section{Concluding remarks and avenues for future research}

Accountability and governance are tangled in their nature and even more when dealing with a global challenge such as climate change. This study attempts to depict an approach for analysing accountability for climate change adopting an IT approach to explore the connectivity amongst the governance, strategy, performance and prospects in climate action. Grounded on "The Climate Governance Triangle", it embraces three - so far separated - accountability dimensions (i.e. Answerability, Enforcement and Outcome). This way, it gets to the development of the Climate Accountability Circle, which stems from the climate governance triangle and expands open issues of accountability at its vertexes.

The IT lens shows a "disintegrated" state of the art with several "non-communicating" themes in the three dimensions used to read the issue from 1998 to date, which is not consistent with the need for expanded and dialogical accountability patterns. The absence of an integrated approach to accountability for climate change resulted in a loss of connectivity amongst internal and external factors, which impact the effectiveness of actions. Neglecting these connections lead to weak motivations, fragmented and confusing performances and unsatisfactory ultimate results achieved. The proposed integrated accountability framework attempts to fill the disintegration, representing a pillar for scholars interested in narrowing their studies on accountability for climate change, bearing in mind an overview of the current landscape. Besides, it would be a matter of interest for policymakers interested in boosting and leaning existing initiatives by capturing existing overlaps and intricate schemes that characterise the transnational complex regime for climate change. Finally, even if focussed on a specific theme as climate change is, on the ground of the IT approach, this study would be helpful for people engaged in the revision of the IR framework, which is underway (IIRC, 2020a, 2020b) and, more in general, in the development of accounting and accountability tools to sustain the complex and pluralistic dialogues throughout the climate war.

\section{References}

Abbott, K.W. (2012), "The transnational regime complex for climate change", Environment and Planning C: Government and Policy, Vol. 30 No. 4, pp. 571-590. 
MEDAR 29,4

Abdi, A., Taghipour, S. and Khamooshi, H. (2018), "A model to control environmental performance of project execution process based on greenhouse gas emissions using earned value management", International Journal of Project Management, Vol. 36 No. 3, pp. 397-413.

Adams, C. (2017), Understanding Integrated Reporting: The Concise Guide to Integrated Thinking and the Future of Corporate Reporting, Routledge, London.

Al-Htaybat, K. and von Alberti-Alhtaybat, L. (2017), "Big data and corporate reporting: impacts and paradoxes", Accounting, Auditing and Accountability Journal, Vol. 30 No. 4, pp. 850-873.

Amran, A., Periasamy, V. and Zulkafli, A.H. (2014), "Determinants of climate change disclosure by developed and emerging countries in Asia pacific", Sustainable Development, Vol. 22 No. 3, pp. 188-204.

Andrew, J. and Cortese, C. (2011), "Accounting for climate change and the self-regulation of carbon disclosures”, Accounting Forum, Vol. 35 No. 3, pp. 130-138.

Ascui, F. and Lovell, H. (2012), "Carbon accounting and the construction of competence", Journal of Cleaner Production, Vol. 36, pp. 48-59.

Atkins, J., Atkins, B.C., Thomson, I. and Maroun, W. (2015), “'Good' news from nowhere: imagining Utopian sustainable accounting", Accounting, Auditing and Accountability, Vol. 28 No. 5, pp. 651 -670.

Backman, C.A., Verbeke, A. and Schulz, R.A. (2017), "The drivers of corporate climate change strategies and public policy: a new resource-based view perspective", Business and Society, Vol. 56 No. 4, pp. $545-575$.

Bäckstrand, K. (2008), “Accountability of networked climate governance: the rise of transnational climate partnerships", Global Environmental Politics, Vol. 8 No. 3.

Barnabè, F. and Giorgino, M.C. (2013), "Integrating' business model and strategy”, in Busco, C., Frigo, M.L., Riccaboni, A. and Quattrone, P. (Eds), Integrated Reporting. Concepts and Cases That Redefine Corporate Accountability, Springer, pp. 111-126.

Barter, N. (2015), "Natural capital: dollars and cents/dollars and sense", Sustainability Accounting, Management and Policy Journal, Vol. 6 No. 3, pp. 366-373.

Bebbington, J. and Larrinaga-Gonzaléz, C. (2008), "Carbon trading: accounting and reporting issues”, European Accounting Review, Vol. 17 No. 4, pp. 697-717.

Bebbington, J., Brown, J., Frame, B. and Thomson, I. (2007), "Theorizing engagement: the potential of a critical dialogic approach", Accounting, Auditing \&Accountability Journal, Vol. 20 No. 3, pp. 356-381.

Bellucci, M. and Manetti, G. (2017), "Facebook as a tool for supporting dialogic accounting? Evidence from large philanthropic foundations in the United States", Accounting, Auditing and Accountability Journal, Vol. 30 No. 4, pp. 874-905.

Ben-Amar, W. and McIlkenny, P. (2015), "Board effectiveness and the voluntary disclosure of climate change information”, Business Strategy and the Environment, Vol. 24 No. 8, pp. 704-719.

Biermann, F. and Gupta, A. (2011), "Accountability and legitimacy in earth system governance: a research framework", Ecological Economics, Vol. 70 No. 11, pp. 1856-1864.

Biermann, F., Pattberg, P., van Asselt, H. and Zelli, F. (2009), "The fragmentation of global governance architectures: a framework for analysis", Global Environmental Politics, Vol. 9 No. 4, pp. 14-40.

Birnik, A. (2013), "Developing climate change strategy: a framework for managers", Thunderbird International Business Review, Vol. 55 No. 6, pp. 699-717.

Blanco, C., Caro, F. and Corbett, C.J. (2017), "An inside perspective on carbon disclosure”, Business Horizons, Vol. 60 No. 5, pp. 635-646.

Bowen, F. and Wittneben, B. (2011), "Carbon accounting: negotiating accuracy, consistency and certainty across organisational fields", Accounting, Auditing and Accountability Journal, Vol. 24 No. 8, pp. 1022-1036.

Brander, M. (2017), "Comparative analysis of attributional corporate greenhouse gas accounting, consequential life cycle assessment, and project/policy level accounting: a bioenergy case study", Journal of Cleaner Production, Vol. 167, pp. 1401-1414. 
Brander, M., Gillenwater, M. and Ascui, F. (2018), "Creative accounting: a critical perspective on the market-based method for reporting purchased electricity (scope 2) emissions", Energy Policy, Vol. 112, pp. 29-33.

Brouhle, K. and Harrington, D.R. (2009), "Firm strategy and the Canadian voluntary climate challenge and registry (VCR)", Business Strategy and the Environment, Vol. 18 No. 6, pp. 360-379.

Bui, B. and de Villiers, C. (2017), "Business strategies and management accounting in response to climate change risk exposure and regulatory uncertainty", The British Accounting Review, Vol. 49 No. 1, pp. 4-24.

Burritt, R.L., Schaltegger, S. and Zvezdov, D. (2011), "Carbon management accounting: explaining practice in leading German companies”, Australian Accounting Review, Vol. 21 No. 1, pp. 80-98.

Busco, C., Frigo, M., Riccaboni, A. and Quattrone, P. (Eds) (2013), Integrated Reporting: Concepts and Cases That Redefine Corporate Accountability, Springer International Publishing, Cham.

Busco, C., Giovannoni, E., Granà, F. and Izzo, M.F. (2018), "Making sustainability meaningful: aspirations, discourses and reporting practices", Accounting, Auditing and Accountability Journal, Vol. 31 No. 8, pp. 2218-2246.

Cadez, S. and Guilding, C. (2017), "Examining distinct carbon cost structures and climate change abatement strategies in co2 polluting firms", Accounting, Auditing and Accountability Journal, Vol. 30 No. 5, pp. 1041-1064.

CGMA (2014), "Integrated thinking: the next step in integrated reporting", available at: https:// competency.aicpa.org/media_resources/206473-integrated-thinking-the-next-step-in-integratedre/detail (accessed 20 May 2020).

Churet, C., Robeco, S.A.M. and Eccles, R.G. (2014), "Integrated reporting, quality of management and financial performance", Journal of Applied Corporate Finance, Vol. 26 No. 1, pp. 56-64.

Comyns, B. (2016), "Determinants of GHG reporting: an analysis of global oil and gas companies", Journal of Business Ethics, Vol. 136 No. 2, pp. 349-369.

Cooper, S.A., Raman, K.K. and Yin, J. (2018), "Halo effect or fallen angel effect? Firm value consequences of greenhouse gas emissions and reputation for corporate social responsibility", Journal of Accounting and Public Policy, Vol. 37 No. 3, pp. 226-240.

Cotter, J. and Najah, M.M. (2012), "Institutional investor influence on global climate change disclosure practices", Australian Journal of Management, Vol. 37 No. 2, pp. 169-187.

Coulson, A., Adams, C.A., Nugent, M. and Haynes, K. (2015), "Exploring metaphors of capitals and the framing of multiple capitals: challenges and opportunities for $<$ IR $>$ ", Sustainability Accounting, Management and Policy Journal, Vol. 6 No. 3, pp. 290-314.

Csutora, M. and Harangozo, G. (2017), "Twenty years of carbon accounting and auditing - a review and outlook", Society and Economy, Vol. 39 No. 4, pp. 459-480.

Dahlmann, F. and Bullock, G. (2020), "Nexus thinking in business: analysing corporate responses to interconnected global sustainability challenges", Environmental Science and Policy, Vol. 107, pp. 90-98.

Datt, R., Luo, L., Tang, Q. and Mallik, G. (2018), “An international study of determinants of voluntary carbon assurance", Journal of International Accounting Research, Vol. 17 No. 3, pp. $1-20$.

Depoers, F., Jeanjean, T. and Jérôme, T. (2016), "Voluntary disclosure of greenhouse gas emissions: contrasting the carbon disclosure project and corporate reports", Journal of Business Ethics, Vol. 134 No. 3, pp. 445-461.

Deveraux Jennings, P. and Zandbergen, P.A. (1995), "Ecologically sustainable organisations: an institutional approach", Academy of Management Review, Vol. 20 No. 4, pp. 1015-1052.

Dillard, J. and Brown, J. (2014), "Integrated reporting: on the need for broadening out and opening up", Accounting, Auditing and Accountability Journal, Vol. 27 No. 7, pp. 1120-1156. 
MEDAR 29,4
Dillard, J. and Vinnari, E. (2019), “Critical dialogical accountability: from accounting-based accountability to accountability-based accounting", Critical Perspectives on Accounting, Vol. 62, pp. 16-38.

Doda, B., Gennaioli, C., Gouldson, A., Grover, D. and Sullivan, R. (2016), "Are corporate carbon management practices reducing corporate carbon emissions?”, Corporate Social Responsibility and Environmental Management, Vol. 23 No. 5, pp. 257-270.

Dombrowski, K. (2010), "Filling the gap? An analysis of non-governmental organisations responses to participation and representation deficits in global climate governance", International Environmental Agreements: Politics, Law and Economics, Vol. 10 No. 4, pp. 397-416.

Du Toit, E., van Zyl, R. and Schutte, G. (2017), "Integrated reporting by South African companies: a case study”, Meditari Accountancy Research, Vol. 25 No. 4, pp. 654-674.

Dumay, J. and Dai, T. (2017), "Integrated thinking as a cultural control?", Meditari Accountancy Research, Vol. 25 No. 4, pp. 574-604.

Dumay, J., Bernardi, C., Guthrie, J. and Demartini, P. (2016), "Integrated reporting: a structured literature review", Accounting Forum, Vol. 40 No. 3, pp. 166-185.

Eleftheriadis, I.M. and Anagnostopoulou, E.G. (2014), "Relationship between corporate climate change disclosures and firm factors", Business Strategy and the Environment, Vol. 24 No. 8, pp. 780-789.

Elijido-Ten, E.O. (2017), "Does recognition of climate change related risks and opportunities determine sustainability performance?”, Journal of Cleaner Production, Vol. 141, pp. 956-966.

Evangelinos, K., Nikolaou, I. and Filho, W.L. (2015), "The effects of climate change policy on the business community: a corporate environmental accounting perspective", Corporate Social Responsibility and Environmental Management, Vol. 22 No. 5, pp. 257-270.

Faisal, F., Andiningtyas, E.D., Achmad, T., Haryanto, H. and Meiranto, W. (2018), "The content and determinants of greenhouse gas emission disclosure: evidence from Indonesian companies", Corporate Social Responsibility and Environmental Management, Vol. 25 No. 6, pp. 1397-1406.

Ferguson, J., Sales de Aguiar, T. and Fearfull, A. (2016), "Corporate response to climate change: language, power and symbolic construction", Accounting, Auditing and Accountability Journal, Vol. 29 No. 2, pp. 278-304.

Flower, J. (2015), "The international integrated reporting council: a story of failure", Critical Perspectives on Accounting, Vol. 27, pp. 1-17.

Gabe, J. (2016), “An empirical comparison of voluntary and mandatory building energy performance disclosure outcomes”, Energy Policy, Vol. 96, pp. 680-687.

Galbreath, J., Charles, D. and Klass, D. (2014), "Knowledge and the climate change issue: an exploratory study of cluster and extra-cluster effects", Journal of Business Ethics, Vol. 125 No. 1, pp. 11-25.

Gallego-Álvarez, I. (2012), "Indicators for sustainable development: relationship between indicators related to climate change and explanatory factors", Sustainable Development, Vol. 20 No. 4, pp. 276-292.

Gasbarro, F., Iraldo, F. and Daddi, T. (2017), "The drivers of multinational enterprises' climate change strategies: a quantitative study on climate-related risks and opportunities", Journal of Cleaner Production, Vol. 160, pp. 8-26.

Giannarakis, G., Zafeiriou, E. and Sariannidis, N. (2017), "The impact of carbon performance on climate change disclosure", Business Strategy and the Environment, Vol. 26 No. 8, pp. 1078-1094.

Grant, R. and Keohane, R. (2005), “Accountability and abuses of power in world politics”, American Political Science Review, Vol. 99 No. 1, pp. 29-43.

Grassmann, M., Fuhrmann, S. and Guenther, T.W. (2019), "Drivers of the disclosed 'connectivity of the capitals': evidence from integrated reports”, Sustainability Accounting, Management and Policy Journal, Vol. 10 No. 5, pp. 877-908.

Grauel, J. and Gotthardt, D. (2016), "The relevance of national contexts for carbon disclosure decisions of stock-listed companies: a multilevel analysis", Journal of Cleaner Production, Vol. 133, pp. 1204-1217. 
Green, J. (2010), "Private standards in the climate regime: the greenhouse gas protocol", Business and Politics, Vol. 12 No. 3, pp. 1-37.

Green, J. (2013), "Order out of chaos: public and private rules for managing carbon", Global Environmental Politics, Vol. 13 No. 2, pp. 1-25.

Hahn, R., Reimsbach, D. and Schiemann, F. (2015), "Organisations, climate change, and transparency: reviewing the literature on carbon disclosure", Organization and Environment, Vol. 28 No. 1, pp. 80-102.

Haque, S. and Azizul Islam, M. (2015), "Stakeholder pressures on corporate climate change-related accountability and disclosures: Australian evidence", Business and Politics, Vol. 17 No. 2, pp. 355-390.

Haque, S. and Irvine, H. (2018), "The climate change-related disclosures and accountability practices of NGOs: evidence from Australia", Financial Accountability and Management, Vol. 34 No. 1, pp. $45-63$.

Haque, F. and Ntim, C.G. (2018), "Environmental policy, sustainable development, governance mechanisms and environmental performance", Business Strategy and the Environment, Vol. 27 No. 3, pp. 415-435.

Harris, P.G., Chow, A.S.Y. and Symons, J. (2012), "Greenhouse gas emissions from cities and regions: international implications revealed by Hong Kong”, Energy Policy, Vol. 44, pp. 416-424.

Hartmann, F., Perego, P. and Young, A. (2013), "Carbon accounting: challenges for research in management control and performance measurement”, Abacus, Vol. 49 No. 4, pp. 539-563, doi: 10.1111/abac.12018.

Hayley, S. and Dryzek, J.S. (2014), Democratizing Global Climate Governance, Cambridge University Press.

Hendrickson, T.P., Nikolic, M. and Rakas, J. (2016), "Selecting climate change mitigation strategies in urban areas through life cycle perspectives", Journal of Cleaner Production, Vol. 135, pp. 1129-1137.

Hoffmann, M. (2011), Climate Governance at the Crossroads: Experimenting with a Global Response after Kyoto: Experimenting with a Global Response after Kyoto, Oxford University Press.

Hoffmann, M. (2016), "The analytic utility (and practical pitfalls) of accountability", Global Environmental Politics, Vol. 16 No. 2, pp. 22-32.

Hrasky, S. (2011), "Carbon footprints and legitimation strategies: symbolism or action?", Accounting, Auditing and Accountability Journal, Vol. 25 No. 1, pp. 174-198.

IIRC (2013), The International $<$ IR $>$ Framework, The International Integrated Reporting Council, London.

IIRC (International Integrated Reporting Council) (2016), "Creating value the cyclical power of integrated thinking and reporting", available at: https://integratedreporting.org/resource/ creating-value-the-cyclical-power-of-integrated-thinking-and-reporting

IIRC (International Integrated Reporting Council) (2019), "Building consensus towards a global system", available at: https://https://integratedreporting.org/integratedreport2019/

IIRC (2020a), The International < IR > Framework - Consultation Draft, The International Integrated Reporting Council, London.

IIRC (2020b), The International $<$ IR $>$ Framework Consultation Draft - Companion Document, The International Integrated Reporting Council, London.

Ioannou, I., Xin Li, S. and Serafeim, G. (2016), "The effect of target difficulty on target completion: the case of reducing carbon emissions", The Accounting Review, Vol. 91 No. 5, pp. 1467-1492.

Jaggi, B., Allini, A., Macchioni, R. and Zagaria, C. (2018), "The factors motivating voluntary disclosure of carbon information: evidence based on italian listed companies", Organization and Environment, Vol. 31 No. 2, pp. 178-202. 
MEDAR 29,4

Jaworska, S. (2018), "Change but no climate change: discourses of climate change in corporate social responsibility reporting in the oil industry", International Journal of Business Communication, Vol. 55 No. 2, pp. 194-219.

Keohane, R.O. (2003), "Global governance and democratic accountability", in Held, D. and KoenigArchibugi, M. (Eds), Taming Globalisation: frontiers of Governance, Polity, Cambridge, pp. 130-159.

Knox-Hayes, J. and Levy, D.L. (2011), "The politics of carbon disclosure as climate governance", Strategic Organization, Vol. 9 No. 1, pp. 91-99.

Kolk, A., Levy, D. and Pinkse, J. (2008), "Corporate responses in an emerging climate regime: the institutionalisation and commensuration of carbon disclosure", European Accounting Review, Vol. 17 No. 4, pp. 719-745.

Kraft, B. (2018), "Shedding light on stakeholder power in a regulated market: a study of variation in electric utilities' climate change disclosures", Organization and Environment, Vol. 31 No. 4, pp. 314-338.

Kramarz, T. and Park, S. (2016), "Accountability in global environmental governance: a meaningful tool for action?”, Global Environmental Politics, Vol. 16 No. 2, pp. 1-22.

Krippendorff, K. (2004), Content Analysis: An Introduction to Its Methodology (2nd ed.), Sage Publications.

Kumarasiri, J. and Gunasekarage, A. (2017), "Risk regulation, community pressure and the use of management accounting in managing climate change risk: Australian evidence", The British Accounting Review, Vol. 49 No. 1, pp. 25-38.

Kuyper, J.W. and Bäckstrand, K. (2016), “Accountability and representation: nonstate actors in UN climate diplomacy”, Global Environmental Politics, Vol. 16 No. 2.

Kuyper, J., Bäckstrand, K. and Schroeder, H. (2017), "Institutional accountability of nonstate actors in the UNFCCC: exit, voice, and loyalty”, Review of Policy Research, Vol. 34 No. 1, pp. 88-109.

Lai, A., Melloni, G. and Stacchezzini, R. (2014), "Corporate sustainable development. is integrated reporting a legitimation strategy?", Business Strategy and the Environment, Vol. 25 No. 3, pp. 165-177.

Laughlin, R. (1996), "Principals and higher principals: accounting for accountability in the caring profession", in Munro, R. and Mouritsen, J. (Eds), Accountability: Power, Ethos and the Technologies of Managing, International Thomson Business Press, London.

Lee, S.Y., Park, Y.S. and Klassen, R.D. (2015), "Market responses to firms' voluntary climate change information disclosure and carbon communication", Corporate Social Responsibility and Environmental Management, Vol. 22 No. 1, pp. 1-12.

Li, D., Huang, M., Ren, S., Chen, X. and Ning, L. (2018), "Environmental legitimacy, green innovation, and corporate carbon disclosure: evidence from CDP china 100", Journal of Business Ethics, Vol. 150 No. 4, pp. 1089-1104.

Liao, L., Luo, L. and Tang, Q. (2015), "Gender diversity, board independence, environmental committee and greenhouse gas disclosure", The British Accounting Review, Vol. 47 No. 4, pp. 409-424.

Liesen, A., Hoepner, A.G., Patten, D.M. and Frank, F. (2015), "Does stakeholder pressure influence corporate GHG emissions reporting? Empirical evidence from Europe", Accounting, Auditing and Accountability Journal, Vol. 28 No. 7, pp. 1047-1074.

Linnenluecke, M.K., Birt, J. and Griffiths, A. (2015), "The role of accounting in supporting adaptation to climate change", Accounting and Finance, Vol. 55 No. 3, pp. 607-625.

Liu, Z., Abhayawansa, S., Jubb, C. and Perera, L. (2017), "Regulatory impact on voluntary climate change-related reporting by Australian government-owned corporations", Financial Accountability and Management, Vol. 33 No. 3, pp. 264-283.

Liu, J., Hull, V., Godfray, H.C.J., Tilman, D., Gleick, P., Hoff, H., Pahl-Wostl, C., Xu, Z., Chung, M.G., Sun, J. and Li, S. (2018), "Nexus approaches to global sustainable development", Nature Sustainability, Vol. 1 No. 9, pp. 466-476. 
Lodhia, S. and Martin, N. (2012), "Stakeholder responses to the national greenhouse and energy reporting act: an agenda setting perspective", Accounting, Auditing and Accountability Journal, Vol. 25 No. 1, pp. 126-145.

Lockwood, M. (2010), "Good governance for terrestrial protected areas: a framework, principles and performance outcomes", Journal of Environmental Management, Vol. 91 No. 3, pp. 754-766.

Lovell, H. (2014), "Climate change, markets and standards: the case of financial accounting”, Economy and Society, Vol. 43 No. 2, pp. 260-284.

Luo, L., Tang, Q. and Lan, Y. (2013), "Comparison of propensity for carbon disclosure between developing and developed countries", Accounting Research Journal, Vol. 26 No. 1, pp. 6-34.

McNally, M.A., Cerbone, D. and Maroun, W. (2017), "Exploring the challenges of preparing an integrated report”, Meditari Accountancy Research, Vol. 25 No. 4, pp. 481-504.

Macho-Stadler, I. and Perez-Castrillo, D. (2006), "Optimal enforcement policy and firms' emissions and compliance with environmental taxes", Journal of Environmental Economics and Management, Vol. 51 No. 1, pp. 110-131.

Mashaw, J. (2006), "Accountability and institutional design: some thoughts of the grammar of governance", in Dowdle, M. (Ed.), Public Accountability. Designs, Dilemmas and Experiences, Cambridge University Press, Cambridge, pp. 115-156.

Massaro, M., Dumay, J. and Guthrie, J. (2016), "On the shoulders of giants: undertaking a structured literature review in accounting", Accounting, Auditing and Accountability Journal, Vol. 29 No. 5, pp. 767-801.

Matisoff, D.C. (2013), "Different rays of sunlight: understanding information disclosure and carbon transparency", Energy Policy, Vol. 55, pp. 579-592.

Matsumura, E.M., Prakash, R. and Vera-Muñoz, S.C. (2014), "Firm-value effects of carbon emissions and carbon disclosures", The Accounting Review, Vol. 89 No. 2, pp. 695-724.

Melloni, G., Stacchezzini, R. and Lai, A. (2016), "The tone of business model disclosure: an impression management analysis of the integrated reports", Journal of Management and Governance, Vol. 20 No. 2, pp. 295-320.

Michalisin, M. and Stinchfield, B. (2010), "Climate change strategies and firm performance: an empirical investigation of the natural resource-based view of the firm", Journal of Business Strategies, Vol. 27 No. 2, pp. 123-149.

Miles, M.B. and Huberman, A.M. (1994), Qualitative Data Analysis: An Expanded Sourcebook, 2nd ed., Sage Publications.

Milne, M.J. and Gray, R. (2013), "W(h)ither ecology? The triple bottom line, the global reporting initiative, and corporate sustainability reporting", Journal of Business Ethics, Vol. 118 No. 1, pp. 13-29.

Mio, C. (Ed.) (2016), "Integrated reporting: the IIRC framework", Integrated Reporting - A New Accounting Disclosure, Palgrave Macmillan, London, pp. 1-19.

Mio, C. and Fasan, M. (2016), "IR: the big promise and the expectation gap", in Mio, C. (Ed.), Integrated Reporting: A New Accounting Disclosure, Palgrave Macmillan, London, pp. 287-300.

Mózner, Z.V. (2013), "A consumption-based approach to carbon emission accounting-sectoral differences and environmental benefits", Journal of Cleaner Production, Vol. 42, pp. 83-95.

Newell, P. (2008), "Civil society, corporate accountability and the politics of climate change", Global Environmental Politics, Vol. 8 No. 3, pp. 122-153.

Nurunnabi, M. (2016), "Who cares about climate change reporting in developing countries? The market response to, and corporate accountability for, climate change in Bangladesh", Environment, Development and Sustainability, Vol. 18 No. 1, pp. 157-186.

Oliver, J., Gillian, V. and Brooks, A. (2016), "Conceptualising integrated thinking in practice", Managerial Auditing Journal, Vol. 31 No. 2, pp. 228-248.

Pitrakkos, P. and Maroun, W. (2019), "Evaluating the quality of carbon disclosures", Sustainability Accounting, Management and Policy Journal, Vol. 11 No. 3, pp. 553-589. 
MEDAR 29,4

Rached, D. (2016), “The concept(s) of accountability: form in search of substance”, Leiden Journal of International Law, Vol. 29 No. 2, pp. 317-342.

Ratnatunga, J.T.D. and Balachandran, K.R. (2009), "Carbon business accounting: the impact of global warming on the cost and management accounting profession", Journal of Accounting, Auditing and Finance, Vol. 24 No. 2, pp. 333-355.

Sakhel, A. (2017), “Corporate climate risk management: are European companies prepared?", Journal of Cleaner Production, Vol. 165, pp. 103-118.

Schaltegger, S. and Csutora, M. (2012), "Carbon accounting for sustainability and management. status quo and challenges", Journal of Cleaner Production, Vol. 36, pp. 1-16.

Schedler, A., Diamond, L. and Plattner, M. (1999), "The Self-Restraining State: Power and Accountability in New Democracies, Lynne Rienner, Boulder, CO.

Scobie, M. (2016), "Policy coherence in climate governance in Caribbean small island developing states", Environmental Science and Policy, Vol. 58, pp. 16-28.

Scobie, M. (2018), "Accountability in climate change governance and Caribbean SIDS", Environment, Development and Sustainability, Vol. 20 No. 2, pp. 769-787.

Silvestri, A., Veltri, S., Venturelli, A. and Petruzzelli, S. (2017), "A research template to evaluate the degree of accountability of integrated reporting: a case study", Meditari Accountancy Research, Vol. 25 No. 4, pp. 675-704.

Solomon, J. and Maroun, W. (2012), Integrated Reporting: The Influence of King III on Social, Ethical and Environmental Reporting, The Association of Chartered Certified Accountants, London.

Smith, M. (2003), Research Methods in Accounting, Sage Publications.

Stanny, E. and Ely, K. (2008), "Corporate environmental disclosures about the effects of climate change", Corporate Social Responsibility and Environmental Management, Vol. 15 No. 6, pp. 338-348.

Steenkamp, N. and Northcott, D. (2008), "Content analysis in accounting research: the practical challenges", Australian Accounting Review, Vol. 17 No. 43, pp. 12-25.

Suchman, M.C. (1995), "Managing legitimacy: strategic and institutional approaches", Academy of Management Review, Vol. 20 No. 3, pp. 571-610.

Talbot, D. and Boiral, O. (2018), "GHG reporting and impression management: an assessment of sustainability reports from the energy sector", Journal of Business Ethics, Vol. 147 No. 2, pp. 367-383.

Tang, S. and Demeritt, D. (2018), "Climate change and mandatory carbon reporting: impacts on business process and performance", Business Strategy and the Environment, Vol. 27 No. 4, pp. 437-455.

Task Force on Climate Related Financial Disclosure (2020), "Status report", available at: https://assets. bbhub.io/company/sites/60/2020/09/2020-TCFD_Status-Report.pdf

Thistlethwaite, J. and Wood, M.O. (2018), "Insurance and climate change risk management: rescaling to look beyond the horizon”, British Journal of Management, Vol. 29 No. 2, pp. 279-298.

Trotman, A.J. and Trotman, K.T. (2015), "Internal audit's role in GHG emissions and energy reporting: evidence from audit committees, senior accountants, and internal auditors", Auditing: A Journal of Practice and Theory, Vol. 34 No. 1, pp. 199-230.

Turner, J.M. (2014), "Counting carbon: the politics of carbon footprints and climate governance from the individual to the global", Global Environmental Politics, Vol. 14 No. 1, pp. 59-78.

Unerman, J. (2007), "Stakeholder engagement and dialogue", in Unerman, J., Bebbington, J. and O’Dwyer, B. (Eds), Sustainability Accounting and Accountability, Routledge, London.

Van Liempd, D. and Busch, J. (2013), "Biodiversity reporting in Denmark", Accounting, Auditing and Accountability Journal, Vol. 26 No. 5, pp. 833-872.

Vesty, G., Brooks, A. and Oliver, J. (2015), "Contemporary capital investment appraisal from a management accounting and integrated thinking perspective: case study evidence", available at: www.cpaaustralia.com.au/professional-resources/sustainability/the-future-ofcapital-investment (accessed 4 august 2020). 
Vitolla, F., Raimo, N. and Rubino, M. (2019), “Appreciations, criticisms, determinants, and effects of integrated reporting: a systematic literature review", Corporate Social Responsibility and Environmental Management, Vol. 26 No. 2, pp. 518-528.

Climate change

Wegener, M., Elayan, F.A., Felton, S. and Li, J. (2013), "Factors influencing corporate environmental disclosures", Accounting Perspectives, Vol. 12 No. 1, pp. 53-73.

Weinhofer, G. and Hoffmann, V.H. (2010), "Mitigating climate change - how do corporate strategies differ?", Business Strategy and the Environment, Vol. 19 No. 2, pp. 77-89.

Widerberg, O. and Pattberg, P. (2017), "Accountability challenges in the transnational regime complex for climate change", Review of Policy Research, Vol. 34 No. 1, pp. 68-87.

Widerberg, O., Pattberg, P. and Kristensen, K. (2016), "Mapping the institutional architecture of global climate change governance V.2", Institute for Environmental Studies (IVM), Amsterdam, available at: http://fragmentation.eu/wp-content/uploads/2016/06/Technical-report-Climatechange-R16-02-FINAL.pdf

Yang, H.H. and Farley, A. (2016), "Convergence or divergence? Corporate climate-change reporting in China", International Journal of Accounting and Information Management, Vol. 24 No. 4, pp. 391-414.

Zengerling, C. (2018), "Action on climate change mitigation in German and Chinese cities - a search for emerging patterns of accountability", Habitat International, Vol. 75, pp. 147-153.

Ziegler, A., Busch, T. and Hoffmann, V.H. (2011), "Disclosed corporate responses to climate change and stock performance: an international empirical analysis", Energy Economics, Vol. 33 No. 6, pp. 1283-1294.

\section{Further reading}

Gray, R. (1992), "Accounting and environmentalism: an exploration of the challenge of gently accounting for accountability, transparency and sustainability", Accounting, Organisations and Society, Vol. 17 No. 5, pp. 399-425.

Sinclair, A. (1995), "The chameleon of accountability: forms and discourses", Accounting, Organisations and Society, Vol. 20 Nos 2/3, pp. 219-237. 


\begin{tabular}{l} 
MEDAR \\
29,4 \\
1032 \\
\hline
\end{tabular}

Table A1.

Reviewed studies classified according to year; journal; scientific field(s), (based on SCImago Journal Rankings); governance architecture (based on Widerberg et al. 2016 classification); accountability dimension(s) addressed

\section{Appendix 1}
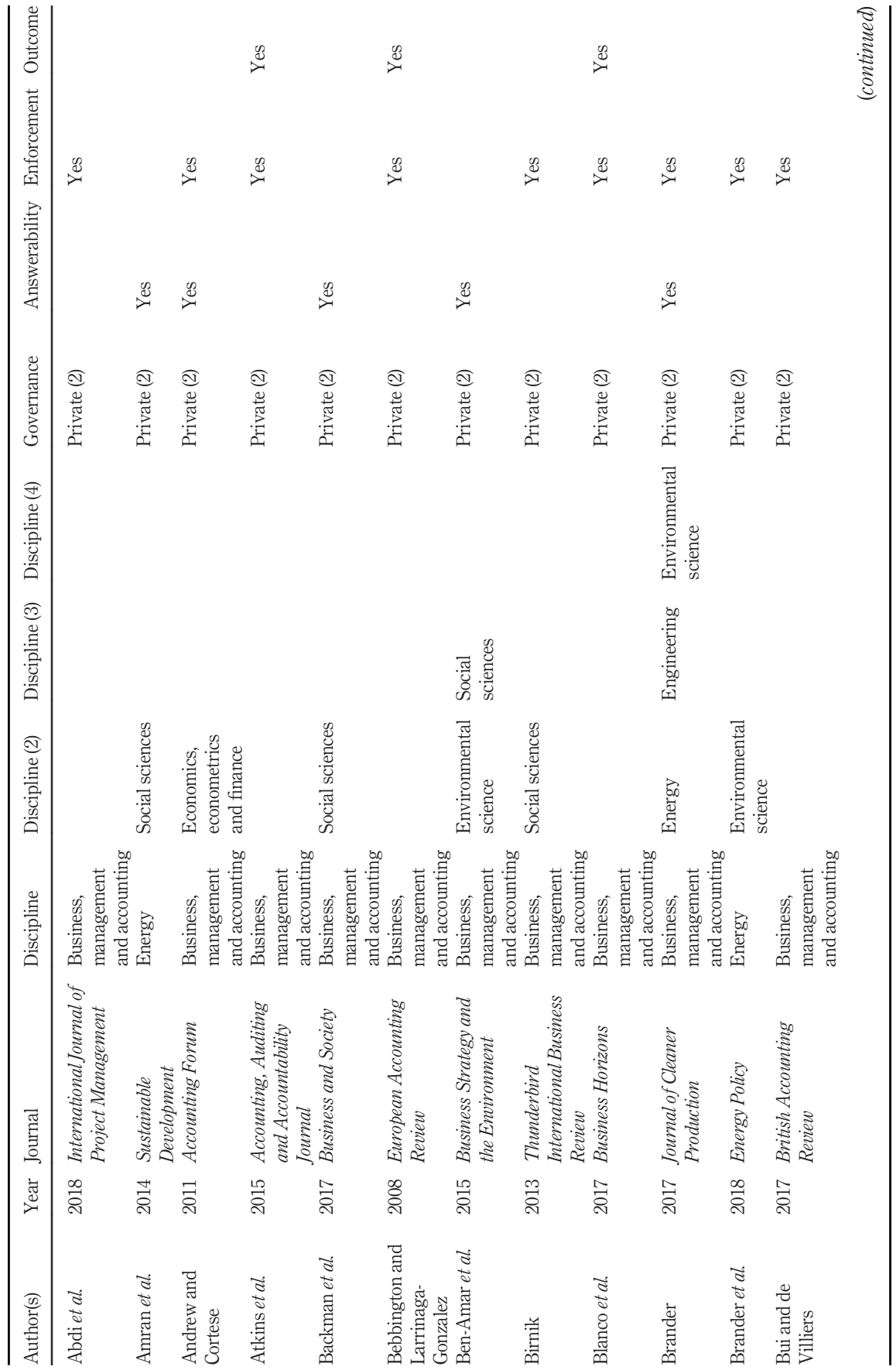


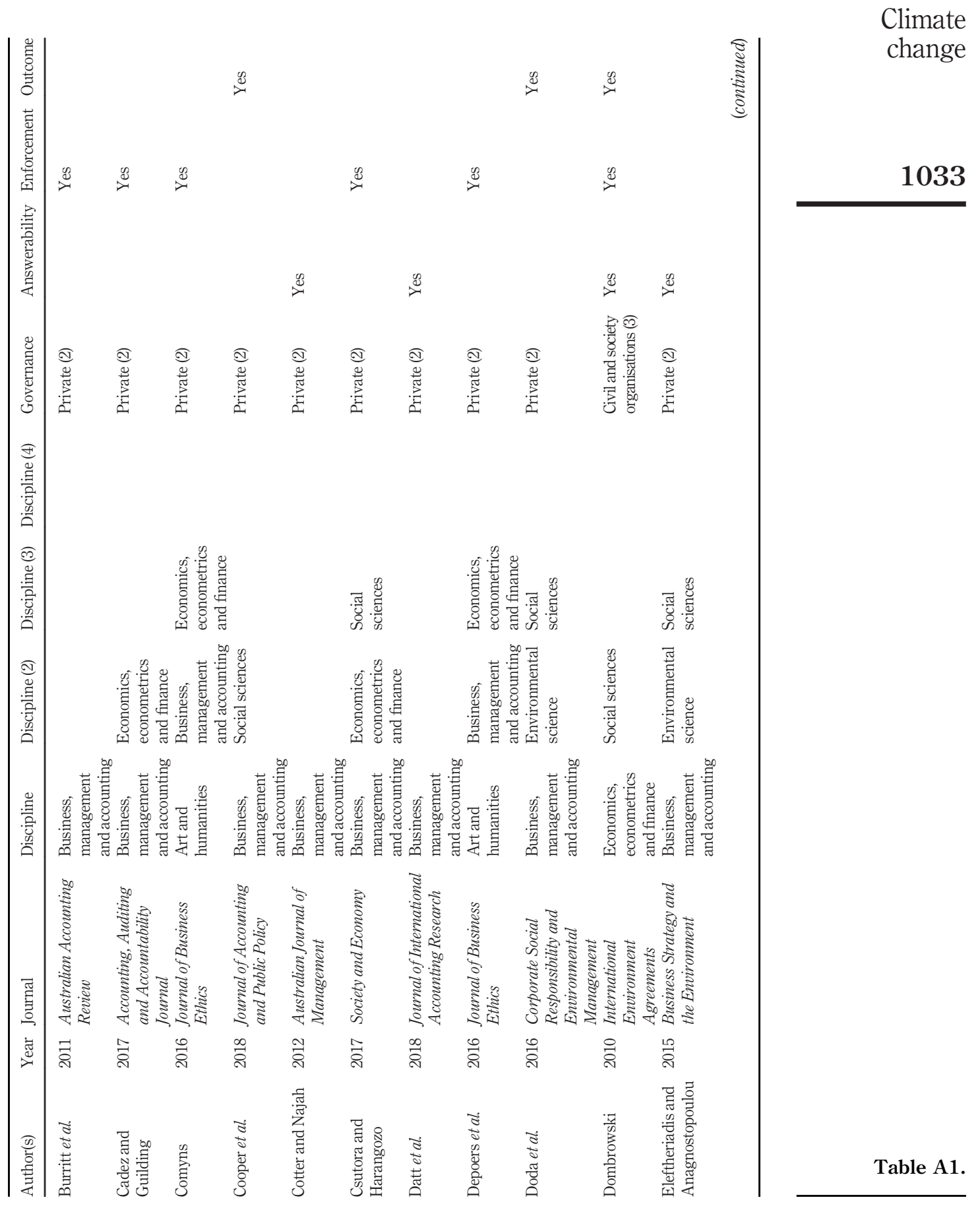


MEDAR

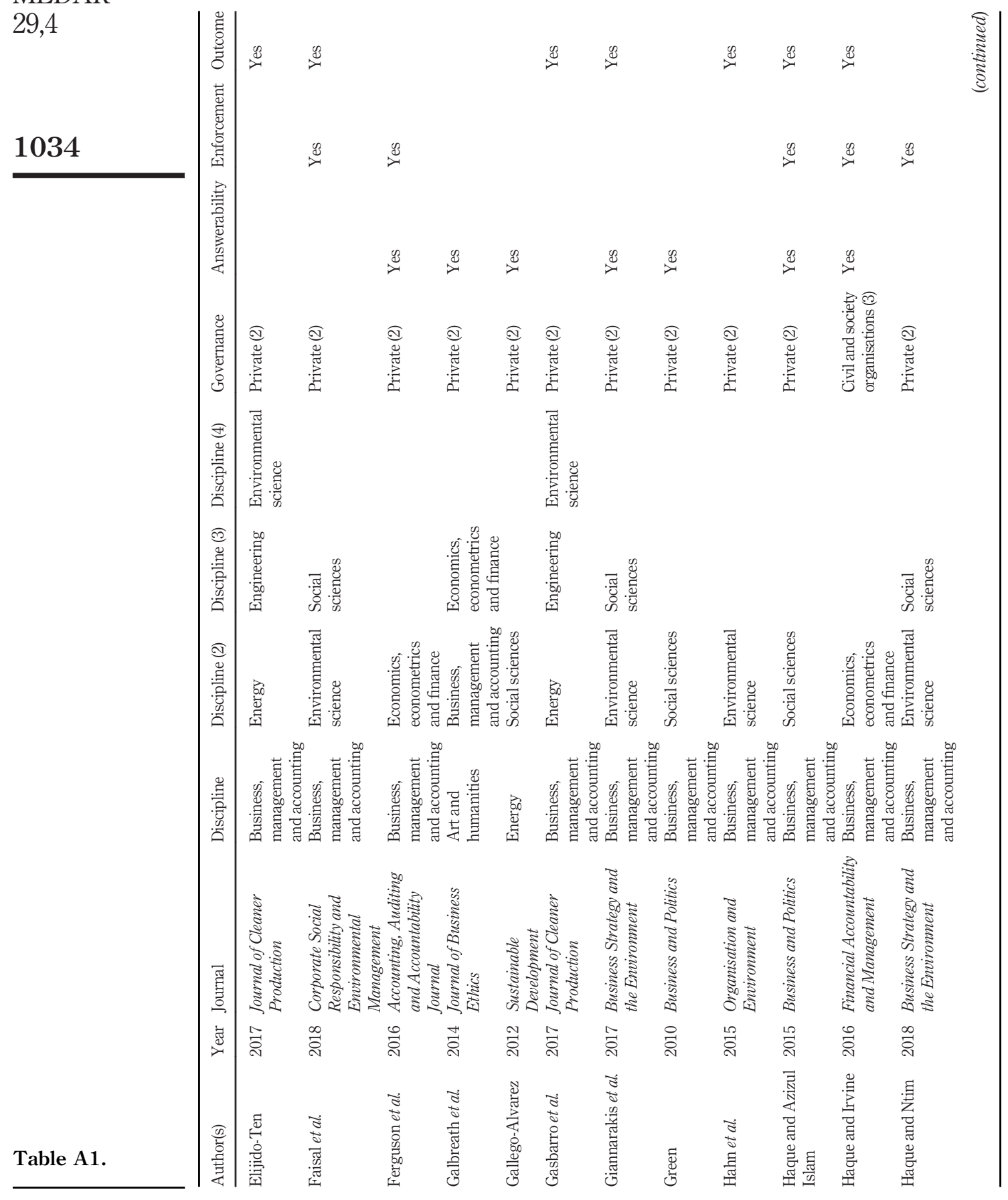




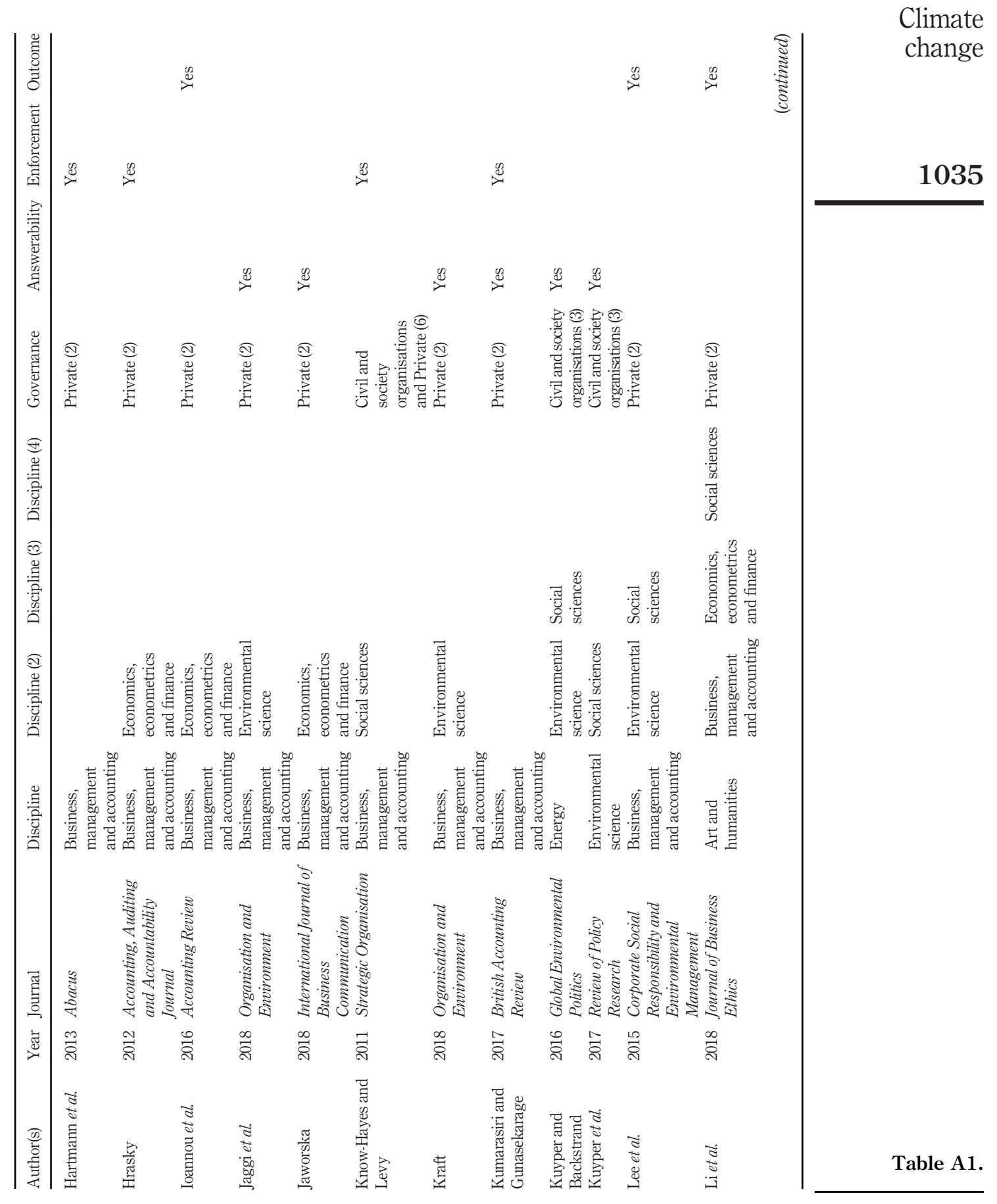


MEDAR

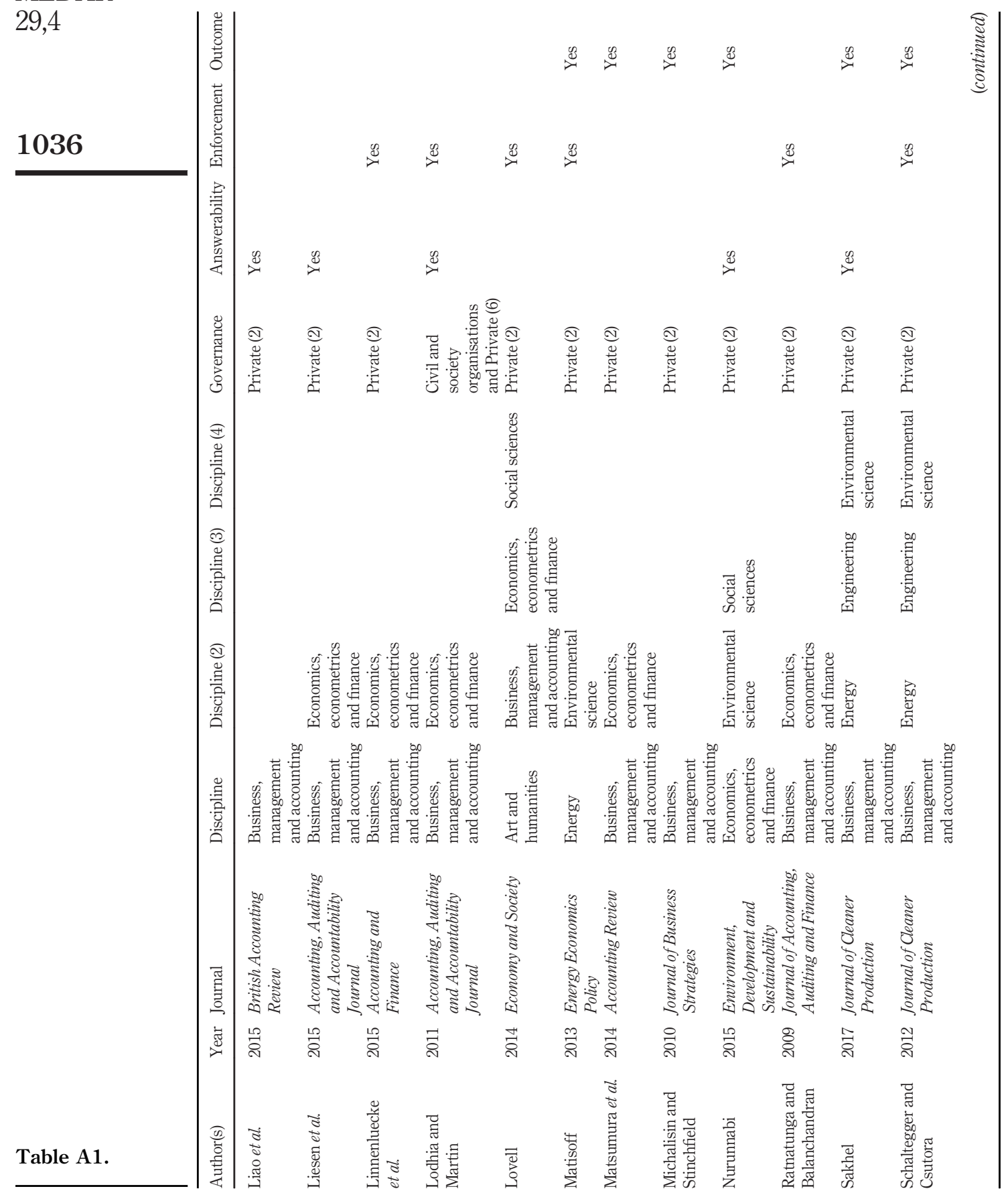




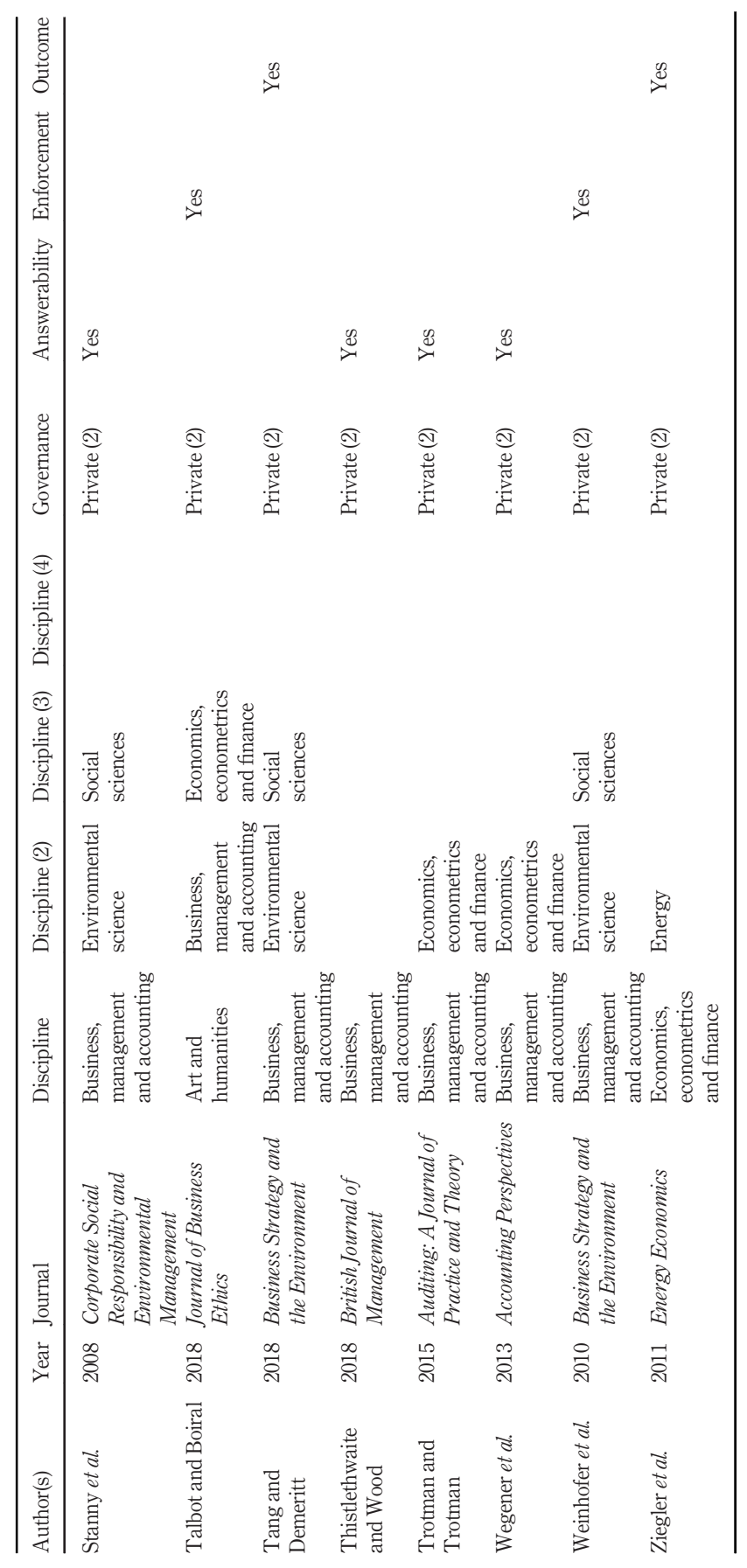

Climate change

1037 
MEDAR

29,4

1038

\section{Appendix 2}

NODES LIST

Answerability

\#A1: private companies, public sector and NGOs,

\#A2: external pressure,

\#A3: media's magnitude,

\#A4: climate mitigation commitment leverage,

\#A5: developing countries vs developed countries,

\#A6: internal and external auditing.

\section{Enforcement}

\#E1: climate accounting,

\#E2: standards and protocols,

\#E3: customisation of disclosure,

\#E4: climate change strategy,

\#E5: climate-related management control research,

\#E6: collaboration amongst stakeholder groups.

\section{Outcome}

\#O1: halo effect vs fallen angel effect of voluntary sustainability practices,

\#O2: financial and non-financial impact,

\#O3: environmental performance,

\#04: market performance impact,

\#05: sector-related magnitude,

\#O6: reputational benefits.

\section{Corresponding author}

Sandro Brunelli can be contacted at: brunelli@economia.uniroma2.it

For instructions on how to order reprints of this article, please visit our website: 